GSA Data Repository 2016341

\title{
Trace elements in fluid inclusions of sediment-hosted gold de- posits indicate a magmatic-hydrothermal origin of the Carlin ore trend
}

\author{
By Simon J.E. Large, Edine Y.N. Bakker, Philipp Weis, Markus \\ Wälle, Mike Ressel and Christoph A. Heinrich \\ GEOLOGY, 2016
}

\section{Geological Background}

\section{Geological background of the Copper Canyon deposit}

Copper Canyon is located in the Battle Mountain Mining district, Nevada, at the northwestern end of the Battle Mountain-Eureka trend (Figure 1). The Copper Canyon area enclosed several mines in the past that were combined into one open pit operation. High-grade ore bodies are largely structurally controlled. Mineralization is bound between multiple faults (Breit et al., 2010). At Copper Canyon, the Cambrian Harmony Formation was thrust over the Devonian Scott Canyon Formation (Fig. DR1). Unconformably overlying the Harmony Formation is the Carboniferous-Permian Antler sequence that was thrust over rocks of the Havallah sequence along the Golconda thrust (Silberling and Roberts, 1962). The sedimentary rock package was intruded by the Eocene Copper Canyon Granodiorite (Theodore et al., 1973) and is locally covered by Eocene tuffs, a Pliocene basalt and alluvium (Breit et al., 2010).

Porphyry-style mineralization is centred on the Copper Canyon porphyry stock but vein mineralization also extends out into the surrounding sedimentary rocks (Breit et al., 2010). Along the margins of the Copper Canyon stock within the hornfelsed Havallah sequence, fracture-controlled mineralization hosts most of the $\mathrm{Au}$ and $\mathrm{Cu}$. Rocks within a radius of up to $3.2 \mathrm{~km}$ underwent hornfels or skarn alteration. Skarn mineralization occurs within a roughly $4.8 \mathrm{~km}$ long north-south trend that is bordered by the Canyon fault in the west and the Virgin fault zone in the east (Breit et al., 2010).

The calcareous Antler Sequence, especially the Antler Peak Formation, is the most important host for ore in the Battle Mountain mining district (Doebrich and Theodore, 1996), but $\mathrm{Cu}$ and Au mineralization is also hosted in rocks from the Harmony Formation up to the Havallah sequence and in the granodioritic intrusion itself (Breit et al., 2010). 


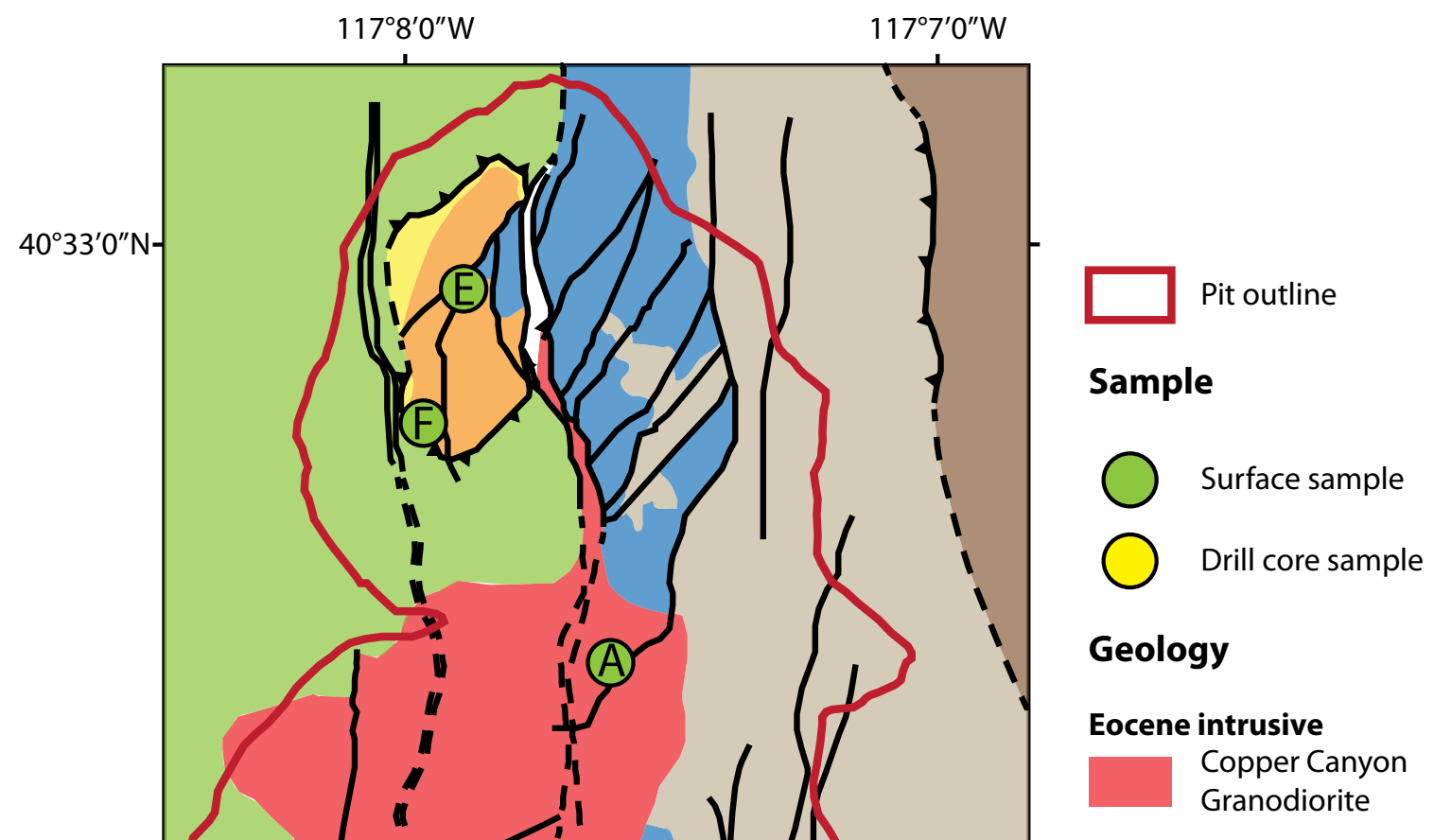

Havallah Sequence

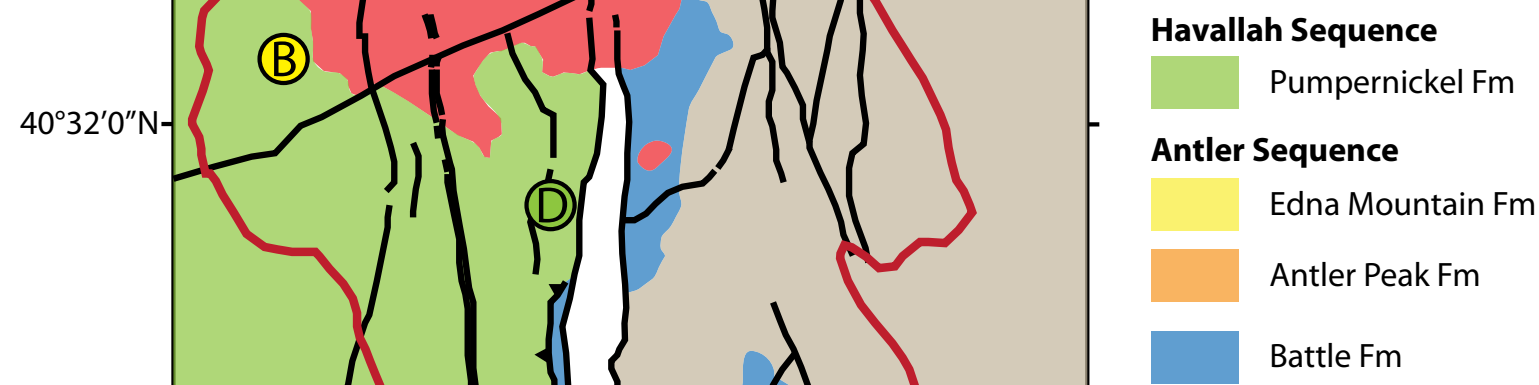

Cambrian

Harmony Fm Scott Canyon Fm

\section{Structure}

- Fault

1. Thrust fault

- - Inferred fault

CF Canyon fault

VF Virgin fault zone

Figure DR1: Plan view of the geology in the Copper Canyon deposit in the Battle Mountain area (after Breit et al., 2010) with sample locations of samples BMA to BMF (circles).

\section{District geology of the Gold Quarry and Chukar deposits}

Samples from the Carlin trend (Fig. 1) analyzed for this study are from the Gold Quarry and the Chukar Footwall deposits which lie directly adjacent to each other in the Maggie Creek District, one of the main Au camps along the Carlin trend, about $10 \mathrm{~km} \mathrm{NE}$ of the town Carlin, NV. The District is situated in the Carlin window where carbonates from below the regional Roberts Mountains Thrust were uplifted and are now exposed at the surface. 
The Good Hope fault is the 'Master Fault' of the Maggie Creek district. It is traceable for nearly $10 \mathrm{~km}$ in the Carlin window and all deposits in the window are aligned on this structure. The highest Au grades occur at intersections of NE-striking faults (e.g. Magpie fault and Deep Sulphide Feeder) with the NW-striking Good Hope fault indicating their role as fluid conduits (Harlan et al., 2002).

Both investigated Carlin-type deposits (Chukar and Gold Quarry) formed within the same stratigraphic sequence with $\mathrm{Au}$ in the Gold Quarry deposit being mainly concentrated in the Devonian Popovich and Rodeo Creek formations whereas Au-ore horizons in the ChukarFootwall deposit are in the underlying Devonian Roberts Mountains Formation (Fig. DR2). These units are lithologically similar to the calc-silicate rocks of the Antler Peak limestone at Battle Mountain (Fig. DR1).

In the Gold Quarry/Chukar area, the contact between the Popovich Formation and the overlying Rodeo Creek Formation is structurally controlled by the Chukar-Alunite fault zone. This fault zone exhibits major decalcification and structural disruptions. Furthermore, it has been proposed as one of the primary ore-controlling structures in the Gold Quarry deposit (Rhys et al., 2015). The Rodeo Creek formation is the top formation of the lower plate in the area and is capped by the regional Roberts Mountains Thrust (Fig. DR2). Rocks of the lower plate are locally metamorphosed to marble or hornfelsed indicating the influence of early magmatic activity in the area (Harlan et al., 2002).

\section{Gold Quarry open pit mine}

The Gold Quarry Mine, with nearly 24 million ounces of total historic production, measured/ indicated reserves, and resources, is the largest gold deposit in the Central Carlin trend (Maggie Creek district) and one of the largest in North America (Harlan et al., 2002).

Gold Quarry shares many characteristics with other typical Carlin-type deposits. Ore occurs in decalcified, silicified, sulfidised and argillised rocks. Intersecting faults, fracture zones and folds acted as fluid conduits and traps. High-grade mineralisation is commonly associated with high-angle collapse breccia bodies (e.g. the Deep Sulphide Feeder; Fig. DR2; Harlan et al., 2002; Rhys et al., 2015). The deposit is structurally controlled by the northwest-striking Good Hope fault and the northeast striking Gold Quarry fault system. The Gold Quarry fault system incorporates numerous variably dipping, northeast-striking faults including the Deep Sulphide Feeder fault zone (Fig. DR2; Rhys et al., 2015).

The Gold Quarry fault zone acts as one of the main feeders not only for the Deep Sulphide feeder orebody but also for the higher Quarry Main and Deep West orebodies (Fig. DR2). High Au grades are generally located at intersections of high-angle northeast-striking faults and northwest-striking faults (e.g. the Good Hope fault; Harlan et al., 2002; Rhys et al., 2015). Anticlines served as additional controlling structures forming traps for ascending hydrothermal fluids (Harlan et al., 2002). A minimum age of mineralization is given by dating of supergene alunite in the deposit that gave an age of $30 \mathrm{Ma}$ (Hofstra et al., 1999)

\section{Chukar underground mine}

The Chukar footwall deposit is located in the footwall of the NE-striking Chukar-Alunite fault system (Fig. DR2). The fault zone is not mineralized but could have acted as a fluid conduit for mineralizing fluids (Parraga, 2005). Au is hosted by silty carbonate rocks and calc-silicate hornfels of the Roberts Mountains formation (Fig. DR2). 


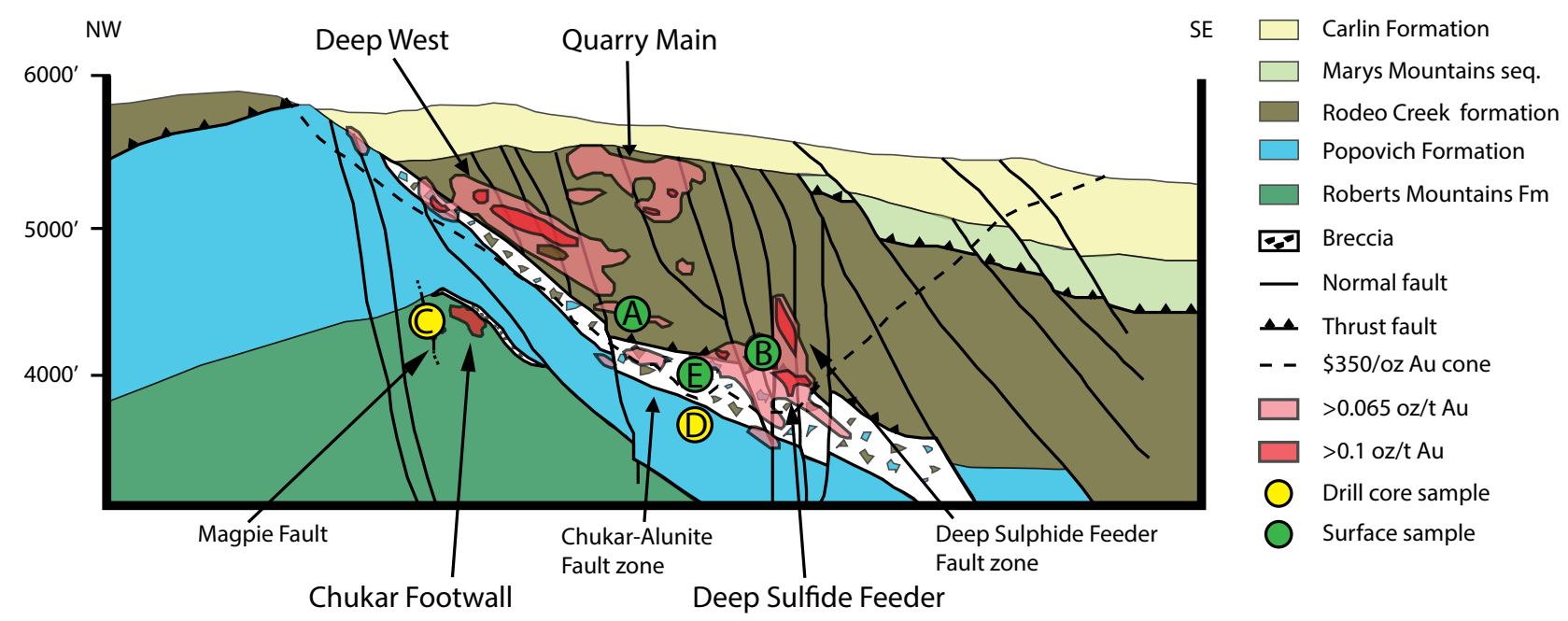

Figure DR2: Schematic geological cross-section through the Gold Quarry and Chukar deposits after Harlan et al. (2002) with sample locations of samples CA to CE (circles).

The Roberts Mountains and Popovich Formations in the Chukar deposit are separated by a brecciated fault zone (Fig. DR2). This fault zone is a large silicified, matrix-supported breccia with angular breccia clasts of the Roberts Mountains Formation and Popovich Formation. The NE-striking brecciated Magpie fault is sub-parallel to the Chukar anticline. It is significantly mineralized and adjacent rocks also show elevated Au-grades suggesting it as one of the main feeder structures (Parraga, 2005).

A pre-Eocene base metal mineralization event $(\mathrm{Cd}, \mathrm{Zn}, \mathrm{Pb}$ and $\mathrm{Ag})$ is recognized around Chukar. However, base metal mineralization is absent in the vicinity to the Au-rich zones (Stammer, 2008).

\section{Sample selection and petrography:}

\section{Copper Canyon samples}

Sample BMA was sampled from the central intrusive porphyry stock, the Copper Canyon Granodiorite (Fig. DR1). Sample BMA is a potassically altered, coarse-grained porphyry rock containing a fine-grained porphyritic xenolith. The rock is cut by classic stockwork quartz veins hosting a wide range of fluid inclusions.

Sample BMB is a drill core sample from the western flank of the intrusive porphyry stock of Copper Canyon (Reona pit). This is one of the areas of the Copper Canyon deposit where the majority of mineralization is hosted by the porphyry stock. The sample shows potassic alteration of the feldspars with a later propyllitic overprint of the biotites. The rock also hosts disseminated sulphides and is cut by pyrite veinlets. A thick quartz vein consisting of $\mathrm{cm}$ sized euhedral quartz grains cuts the rock. Vugs within the big quartz crystals are filled by later drusy quartz and pyrite, sphalerite and arsenopyrite.

Drill core sample BMC was collected from the Minnie pit located to the southeast of the Copper Canyon stock. In the area, mineralized veins occur within the brecciated sediments of 
the Harmony Formation. Disseminated sulphides occur in the sample. The investigated vein contains quartz, chlorite, sericite and pyrite and minor quantities of other sulfides.

Sample BMD was collected from a freshly blasted ore pile of strongly altered Pumpernickel formation within the Havallah sequence. The sample contains a massive quartz vein with fine grained milky quartz at the rim grading to coarser quartz and galena with pyrrhotite and other sulfide inclusions. A broad envelope of chlorite surrounds the quartz vein and later fractures filled with arsenopyrite crosscut the vein.

Sample BME is a surface sample of garnet-pyrrhotite skarn from the Antler sequence. Partly metastable garnet and pyrite occur coevally as large porphyroblasts in a matrix of pyrrhotite and chalcopyrite. The garnet is partly replaced by sulfide minerals and sometimes a thin rim of sphalerite occurs around the garnet. Retrograde "birds-eye" textures of pyrrhotite altered to pyrite and marcasite can also be observed.

Sample BMF is another surface sample from the Antler sequence collected in the pit. The limestone is altered to a garnet pyrrhotite skarn. The garnet is andraditic in composition, indicating prograde skarn alteration. Chalcopyrite is abundant and visible Au is present.

Fluid inclusion data from All Copper Canyon samples are presented in Table DR1.

\section{Gold Quarry - Chukar samples}

Sample CA was collected in the SW wall of the Gold Quarry pit within the Rodeo Creek formation (Fig. DR2). Different vein-types were identified on the bench and the sample is from an early base-metal vein with a younger overprint. The rock was nearly completely oxidised with former Mn-carbonates now occurring as pyrolusite, with assay data showing high base metal concentrations (Table DR3). The rock contains veins of vuggy quartz. Two different quartz generations occur in the rock: (1) Early $\mathrm{cm}$-sized quartz showing undulose extinction; (2) A thick vein of granular, vug-filling quartz that cuts the first quartz generation. The early quartz (1) hosts pyrolusite, euhedral barren pyrites and needles with stibnite-like habits. This quartz generation is most probably the source for the high base metal concentrations. However, it also hosts very fine anhedral pyrites that are aligned along very thin veinlets migrating into the quartz from vugs and cavities, possibly a feature of the later Carlin-event. The later quartz (2) crystals show growth zoning and anhedral Au-bearing pyrite occurs within the quartz. We analysed only fluid inclusions in the later quartz generation that can be clearly texturally associated with the Au-rich anhedral pyrites to eliminate the danger of analyzing fluids of a previous hydrothermal event.

Sample CB (Fig. DR3) was collected in the Gold Quarry pit along the Deep Sulphide feeder in the northeastern part of the pit. The host lithology of siltstone from the Rodeo Creek formation is heavily brecciated and clay altered. Clasts in the matrix-supported breccia are derived from the surrounding lithology and breccia infill minerals include early, fine-grained quartz, followed by drusy or granular quartz, barite and late clay minerals. Notably, there is abundant fine-grained quartz enclosed the breccia clasts and formed in cavities. In other samples, fine-grained quartz crystals only occur as a thin rim around the clasts. Early pyrite veinlets cut breccia clasts of the host lithology and large pyrite crystals are hosted in the matrix. However, the Au-bearing anhedral pyrite only occurs on the $\mu \mathrm{m}$-scale and most is present in the breccia clasts with minor amounts occurring with early fine-grained quartz, later drusy or granular quartz and the associated milky, clay-rich material also have inclusions of Au-bearing pyrite. 
Sample CC was collected from an exploration drill core of the Chukar underground mine. The sampled lithology is black, silty limestone of the Roberts Mountains Formation. The sampled area is in the mineralised Magpie fault system and is therefore highly brecciated with quartz and barite infill. Fine-grained quartz occurs in pores within the silty limestone or silty limestone breccia clasts. The clasts are crosscut by early, fine-grained to drusy quartz veins. These veins terminate at the edge of the clasts by the clay-rich material and associated cavity-fill barite. The silty limestone is the host for the majority of all observed pyrite variations: anhedral, small $(<20 \mu \mathrm{m})$ Au-bearing pyrite; barren, euhedral pyrite; and reworked and rounded pyrite (up to $200 \mu \mathrm{m}$ ). However, small anhedral, Au- and As-rich Carlin ore pyrites also occur in the fine and drusy quartz and clay-rich infill material.

Sample CD is from a drill core through the Popovich Formation about $5 \mathrm{~m}$ beneath the Alunite fault. The sampled area is dominated by a silicic, low-grade, clast-supported breccia ore. The breccia clasts are from the surrounding silty limestones. Spherical vugs in the limestones are filled by fine-grained quartz and this quartz also fills small pores within the clasts. Vug-infill minerals are euhedral quartz followed by large calcite crystals showing twinning. Early euhedral non-ore pyrite is present in the limestone clasts, as is the majority of tiny, anhedral, Au-bearing pyrite though fine grained, anhedral. Au-bearing pyrite is intergrown with the euhedral quartz as well.

Sample CE (Fig. DR4) was collected from the pit at the Alunite fault in the Gold Quarry deposit. The fault is fractured, altered and desilicified. The sample was taken from the centre of the ore zone. Macroscopic pyrites and pyrite veins are mainly barren. On the microscopic scale barren large euhedral pyrites (up to $\mathrm{cm}$ scale) occur in early quartz generations. During a later brecciation event, fragments of pyrite and old quartz occur as clasts in the breccia. The matrix is rich in fine-grained Au-As-rich pyrites and overgrowths of it over early euhedral pyrite fragments. Fine-grained Au-As-rich pyrites together with fluid inclusion assemblages occur in clear euhedral Carlin stage quartz or growth zones over fragments of earlier quartz.

Fluid Inclusion data from all Carlin samples are presented in table DR1.

\section{Sample preparation}

Rock samples were cut to slabs and polished for detailed macroscopic descriptions. 55 samples were prepared for doubly polished thick sections (ca. $200 \mu \mathrm{m}$ ). Detailed microscopic petrography with polarized and reflected light included identification of fluid inclusion assemblages.

Figure DR3 (next page): Breccia from the Deep Sulphide Feeder with Au-As-bearing pyrites associated with different quartz crystals and the calc-silicate host-rock showing the same chemical composition (see also Fig. 1D-G). A: Photo of fractured siltstone clasts and early barren pyrite. Breccia infill by quartz and later clay. B and C: transmitted light and crossed polarized light images, respectively, of breccia with fine-grained quartz infill and later drusy quartz. Small black round features are LAICP-MS pits from fluid inclusion analysis (LA pits). D and E: Images of plane transmitted light and crossed polarized light showing that the pyrite occurs in drusy quartz. GI, II, and III indicate the grains analysed by LA-ICP-MS. The respective signals are shown in G. F: Higher magnification image on the fine-grained quartz zone with numerous small anhedral pyrites. G: LA-ICP-MS signals of different pyrites. Signals I, II, and III are from small anhedral pyrites in the section that show elevated $\mathrm{Au}, \mathrm{As}, \mathrm{Tl}$, and $\mathrm{Sb}$ as is characteristics for typical Carlin ore stage pyrite. The last signal (euhedral pyrite) is from a larger euhedral barren pyrite with no Au and only a minor As. As contents are approximate values with the Fe-content of pure FeS2 being used as the external standard 

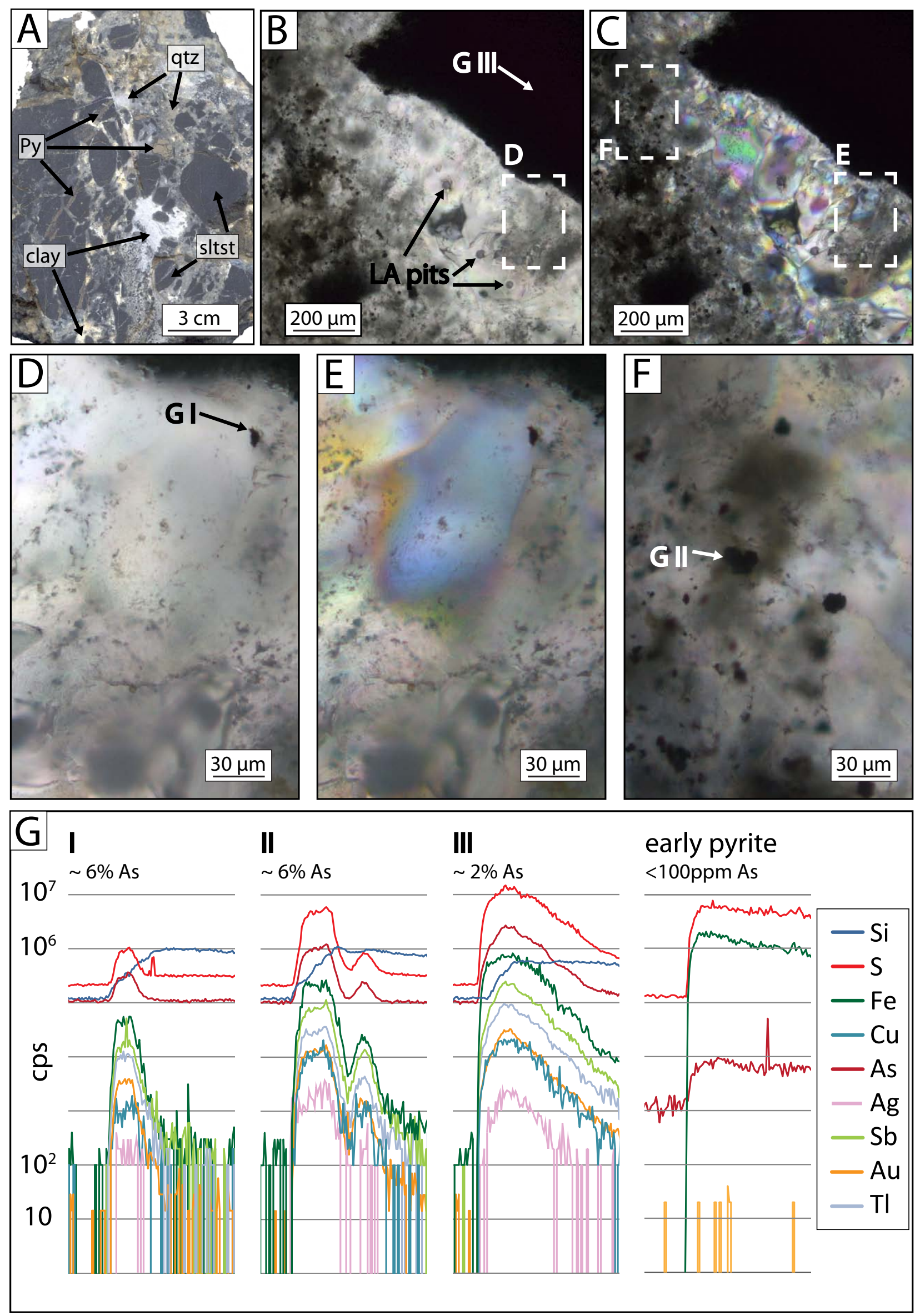
While previous work on Carlin type deposits relied on fluid inclusions hosted in very finegrained ore-stage jasperoid quartz (Cline and Hofstra, 2000; Hofstra and Cline, 2000), this study also investigated primary, pseudosecondary and secondary fluid inclusion assemblages found in quartz within veinlets and breccias interpreted as fluid pathways of the oreforming fluid (Fig. DR3 and DR4). To clearly associate fluid inclusions with the ore-forming event, pyrite inclusions in the different quartz generations were qualitatively analyzed by LA-ICP-MS for their content of Au, As and other trace elements (e.g. DR3 and DR4). Characteristically, euhedral pyrites with varying sizes were esssentially pure $\mathrm{FeS}_{2}$ while small anhedral pyrites (maximum sizes around $100 \mu \mathrm{m}$ ) or pyrite rims on euhedral pyrite cores were Au- and As-rich (Fig. DR3 and DR4; Simon et al., 1999). Fluid inclusions analyzed by LA-ICP-MS (Table DR1) are all hosted in quartz intergrown with Au-bearing arsenian pyrite (Fig. DR3 and DR4). Therefore, we are confident that we obtained chemical analyses of the Au-ore forming fluids at the Carlin-type deposit at Gold Quarry and Chukar.

Fluid inclusion assemblages of samples from Copper Canyon were analysed in quartz and garnet. Here, identification of inclusions containing the ore-forming fluids was easier due to the presence of easily identifiable ore minerals (e.g. chalcopyrite) associated with quartz and garnet. Vapor, brine and aqueous inclusions were identified (Fig. DR5) and analysed by microthermometry and LA-ICP-MS.

\section{Analytical techniques}

Microthermometry of fluid inclusions was conducted on a Linkam THMSG-600 cooling-heating stage that was calibrated against synthetic fluid inclusion standards from SYNFLINC at $-56.6^{\circ} \mathrm{C}, 0.0^{\circ} \mathrm{C}$ and $374.1^{\circ} \mathrm{C}$. Analytical uncertainties of the ice melting temperature and homogenization temperatures are $\pm 0.1^{\circ} \mathrm{C}$ and $\pm 5^{\circ} \mathrm{C}$, respectively.

LA-ICP-MS microanalysis of 94 individual fluid inclusions in samples from Copper Canyon, of 55 fluid inclusions in samples from Chukar and Gold Quarry and on pyrites were performed with a Perkin Elmer Elan 6100 ICP-quadrupole-MS and an Element XR ICP-SectorField-MS connected to a GeoLas $193 \mathrm{~nm}$ ArF excimer laser system. The reference material NIST 610 was used as the internal standard. Analytical procedures followed Heinrich et al. (2003) and Guillong et al. (2008). Analyses of fluid inclusions by LA-ICP-MS recorded B, $\mathrm{Na}, \mathrm{K}, \mathrm{S}, \mathrm{Fe}, \mathrm{Pb}, \mathrm{Zn}, \mathrm{Cu}, \mathrm{Au}, \mathrm{As}, \mathrm{Sb}, \mathrm{Cs}, \mathrm{Ba}, \mathrm{Rb}, \mathrm{Sr}, \mathrm{Tl}$ and $\mathrm{Si}$, though $\mathrm{S}$ and $\mathrm{Au}$ were not clearly detectable. 27 analyses from Chukar and Gold Quarry did not record B, as indicated by a dash in Table DR1. External standardization was based on $\mathrm{Na}$ concentrations calculated from microthermetric data using the model of Bodnar and Vityk (1994). Data reduction

Figure DR4 (facing page): Breccia from the Deep Sulphide Feeder with Au-As-bearing pyrites associated with different quartz crystals and the calc-silicate host-rock showing the same chemical composition (see also Fig. 1D-G). A: Photo of fractured siltstone clasts and early barren pyrite. Breccia infill by quartz and later clay. B and C: transmitted light and cross-polarized light images, respectively, of breccia with fine-grained quartz infill and later drusy quartz. Small black round features are LA-ICP-MS pits from fluid inclusion analysis (LA pits). D and E: Images of plane transmitted light and cross-polarized light showing that the pyrite occurs in drusy quartz. GI, II, and III indicate the grains analysed by LA-ICP-MS. The respective signals are shown in G. F: Higher magnification image of the fine-grained quartz zone with numerous small anhedral pyrites. G: LA-ICP-MS signals of different pyrites. Signals I, II, and III are from small anhedral pyrites in the section that show elevated $\mathrm{Au}, \mathrm{As}, \mathrm{Tl}$, and $\mathrm{Sb}$ as is characteristics for typical Carlin ore stage pyrite. The last signal (euhedral pyrite) is from a larger euhedral barren pyrite with no Au and only minor As. 

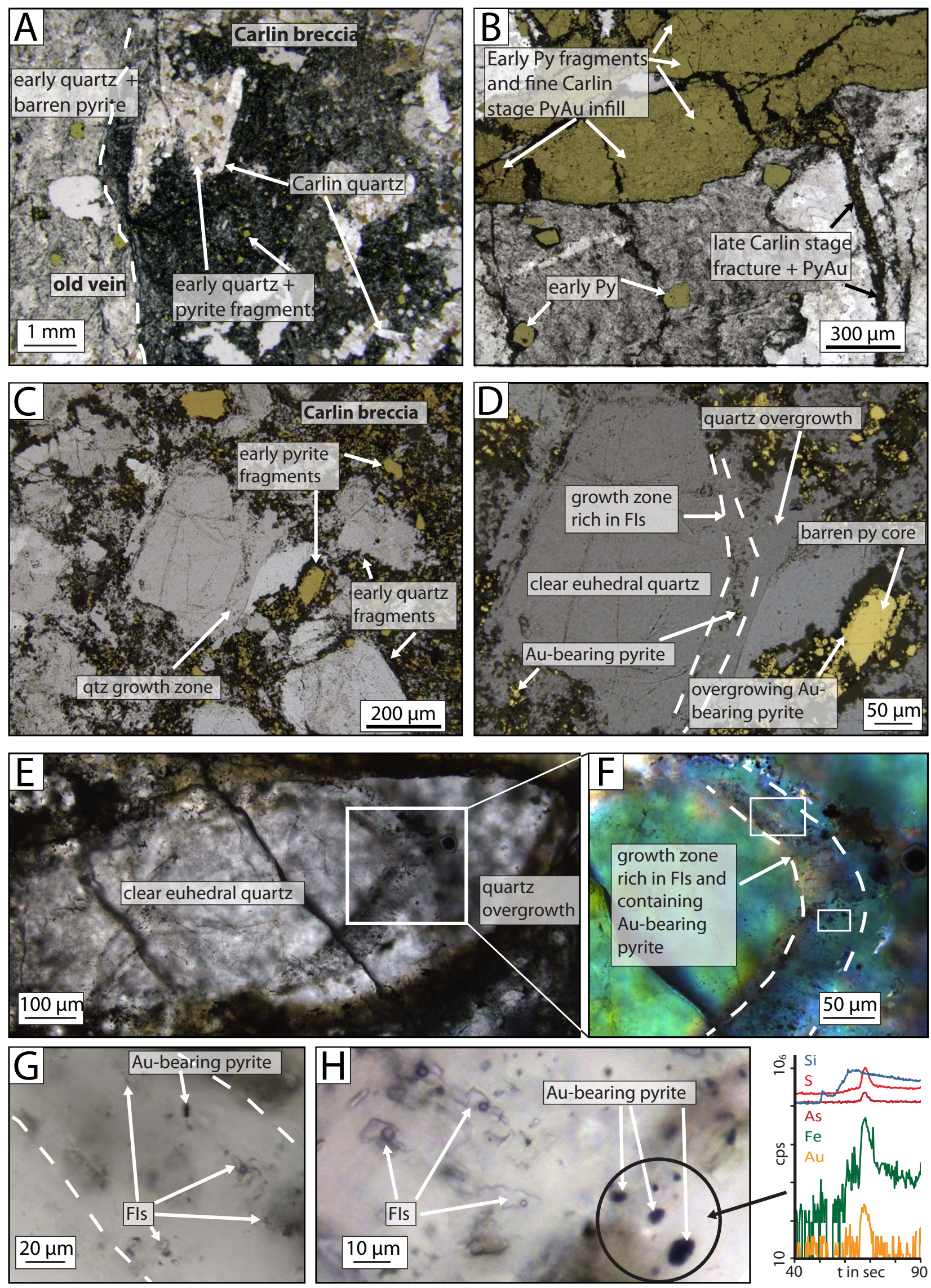

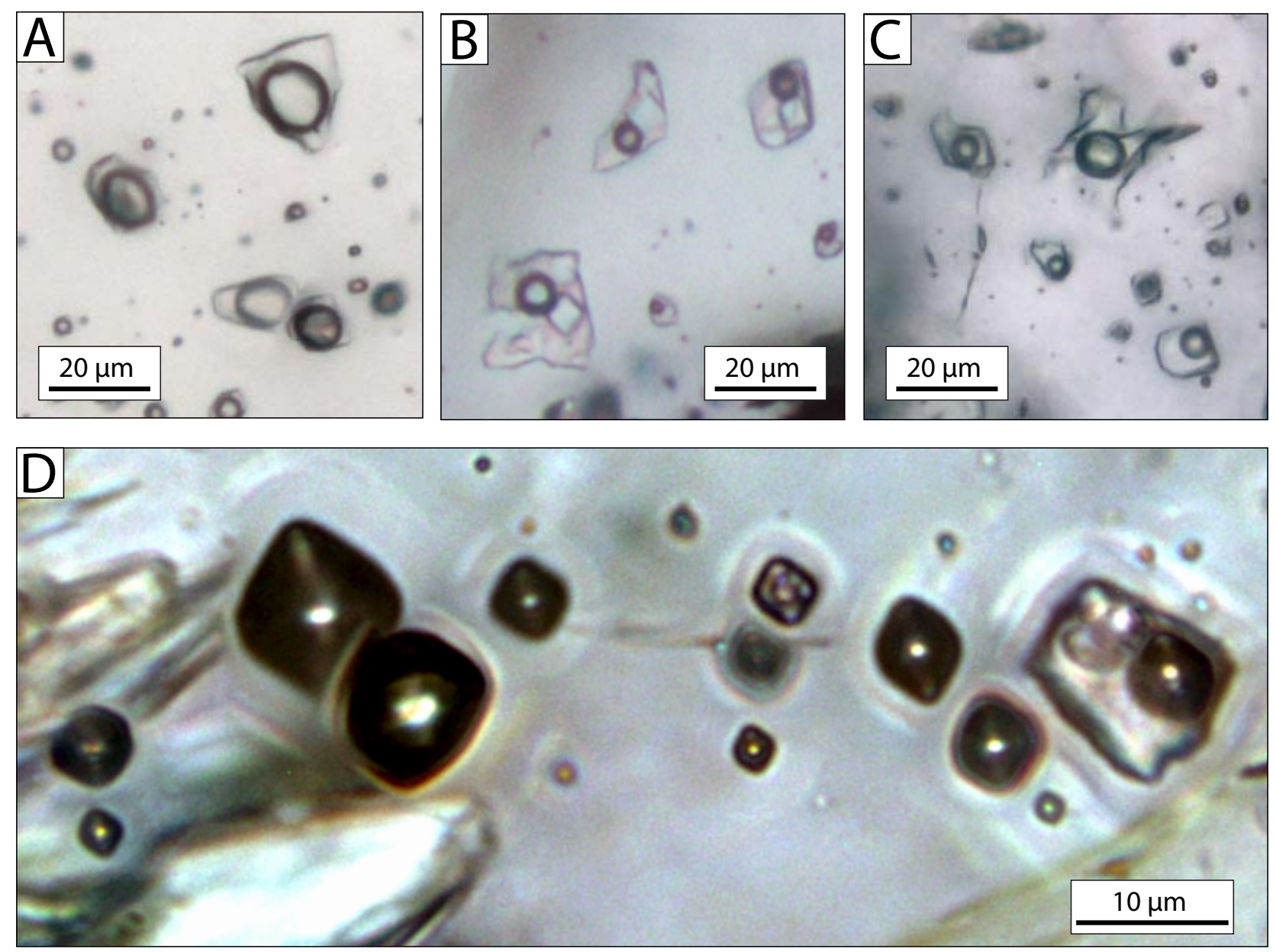

Figure DR5: Fluid inclusion types identified at Battle Mountain (see also Fig. 1D-E). A) Vapor-rich low-density inclusions. B) High-density brine inclusions with entrapped salt crystals. C) Intermediate-density aqueous inclusions. D) Boiling trail of coexisting vapor and brine inclusions.

was carried out using the SILLS (Signal Integration for Laboratory Laser Systems) software package (Guillong et al., 2008). If microthermometry on single inclusions was not possible for optical reasons, the average salinity for the fluid inclusion assemblage was used as the external standard for the respective inclusion and listed at the end of each inclusion assemblage. In some cases ablating an inclusion resulted in two separate inclusion signals. This is attributed to the laser hitting another hidden inclusion beneath the observed inclusion. In these cases the salinity of the visible inclusion was used as the external standard for both signals.

\section{Detection limits and plotting of fluid inclusions}

For each individual fluid inclusion laser ablation analysis, individual limits of detection (LOD) were calculated by SILLS, and only element count intensities showing a notable peak and statistically significant counts above 3xSigma(Background) were considered as detected (Longerich et al., 1996). Table DR1 reports individual inclusion results, as well as averages where several inclusions were analysed in one petrographic fluid inclusion assemblage. 
Data below the detection limit are marked with a '<', indicating that the true value is between 0 and the indicated number.

For illustrations in the ternary diagrams, we used analyses where all three endmembers of a diagram were detected during LA-ICP-MS measurement. For analyses where only two elements for a ternary diagram were detected, the limit of detection (LOD) was used to plot T-bar symbols and a dashed line. The actual data point for these analyses thus falls along the dashed line (see Figure DR 6 for illustration). Analyses where only one element for a ternary diagram was detected were not plotted in the diagrams.

The coloured hexagons in Figure 2 of the paper and in Figure DR7 encompass all analyses of each distinct fluid group from Copper Canyon. For clarity, the yellow vapor fields in Figure 2B combine data points of vapor and contracted vapour inclusions identified at Copper Canyon, but Figure DR7 shows the two fluid-inclusion groups separately to document their compositional similarity. Color gradients indicate where the majority of data points cluster.

\section{Data from published studies}

For comparison with the Carlin and Copper Canyon fluids, fluid inclusion data from Bingham Canyon porphyry deposit, USA (Landtwing et al., 2010), the Mojito skarn deposit, Mexico (Williams-Jones et al., 2010), globally distributed basin brines (Kharaka and Hanor, 2014), ore fluids from the Irish ore field (Wilkinson et al., 2005), MVT deposits in the Tri-state district and northern Arkansas district, USA (Stoffell et al., 2008), metamorphic fluids in the European Alps (Miron et al., 2013) and from the 'Carlin-like' deposits in China (Su et al., 2009) are used. All studies except the overview paper by Kharaka and Hanor (2014) and the paper on Irish-type fluids by Wilkinson et al. (2005) used in-situ analysis of single fluid inclusions by LA-ICP-MS. Kharaka and Hanor (2014) compile fluid inclusion data from all kinds

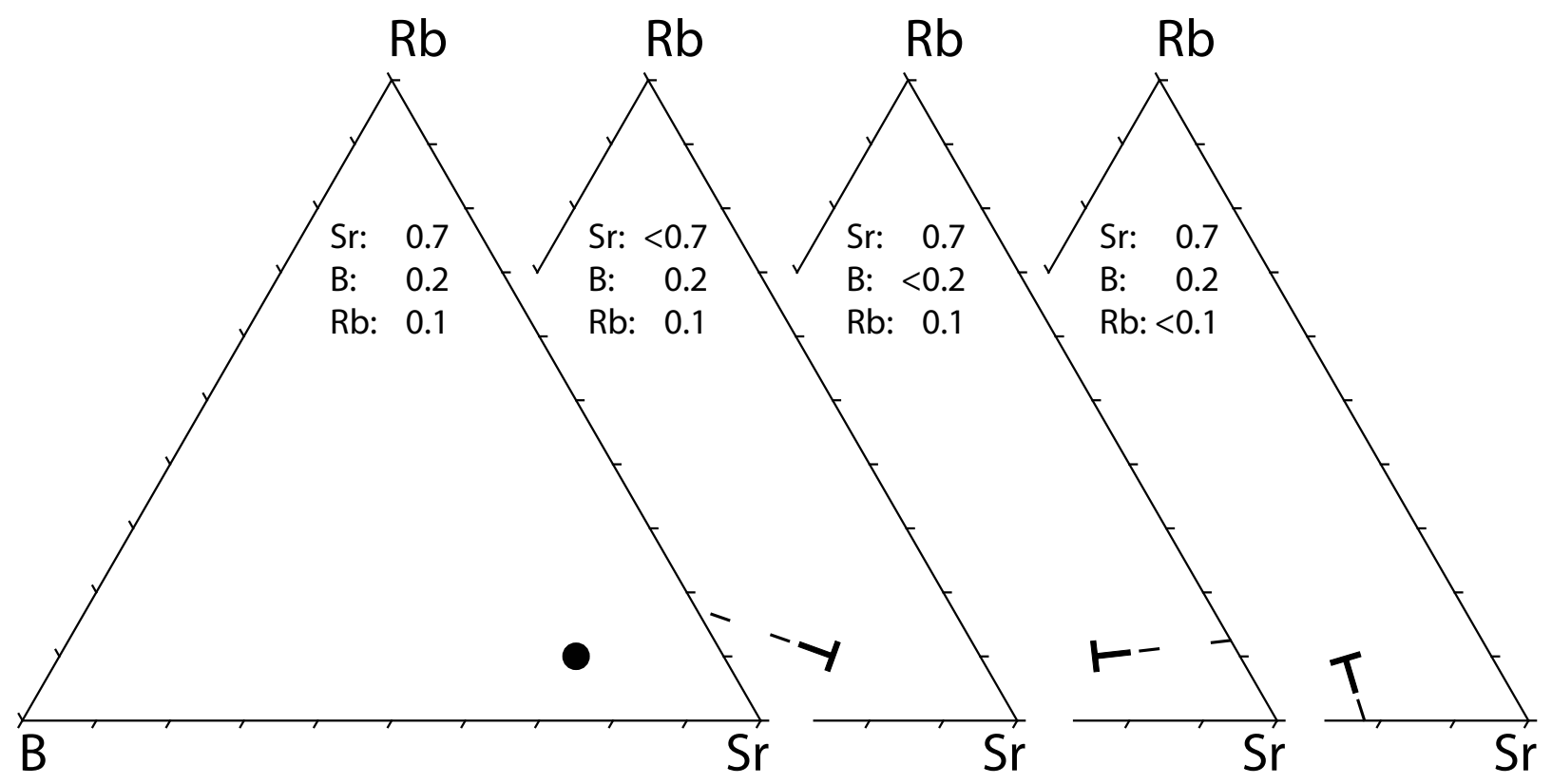

Figure DR6: Example of cricles and t-bar symbols in diagrams 2, 3 and DR 7. In the first triangle all endmembers ( $\mathrm{Sr}, \mathrm{B}$, and $\mathrm{Rb}$ ) were detected and the point is plotted as a dot. In the following three diagrams one of the elments was below the detection limit. The t-bar is plotted using the value of the detection limit but the real value is somewhere on the line leading away from the tip of the t-bar. 
of analysis, while Wilkinson et al. (2005) used the bulk analysis of fluid inclusions using decrepitation linked inductively coupled plasma-atomic-emssion spectrometry (ICP-AES). The average values of all inclusions are used for the calculation of the ratios in the ternary diagrams (Fig. 3).

\section{References}

Bodnar, R., and Vityk, M. O., 1994, Interpretation of microthermometric data for $\mathrm{H} 20-\mathrm{NaCl}$ fluid inclusions: Fluid inclusions in minerals: methods and applications, p. 117-130.

Breit, F., Alvarez, K., Gilmore, A., and McComb, M., 2010, A geologic update from the Battle Mountain district, Newmont's Phoenix Project: Great Basin Evolution and Metallogeny, v. 1, p. 463-488.

Cline, J. S., and Hofstra, A. A., 2000, Ore-fluid evolution at the Getchell Carlin-type gold deposit, Nevada, USA: European Journal of Mineralogy, v. 12, no. 1, p. 195-212.

Doebrich, J., and Theodore, T., 1996, Geologic history of the Battle Mountain mining district, Nevada, and regional controls on the distribution of mineral systems: Geology and ore deposits of the American Cordillera. Geological Society Nevada, Reno, p. 453-483.

Guillong, M., Latkoczy, C., Seo, J. H., Günther, D., and Heinrich, C. A., 2008, Determination of sulfur in fluid inclusions by laser ablation ICP-MS: Journal of Analytical Atomic Spectrometry, v. 23, no. 12, p. 1581-1589.

Harlan, J., Harris, D., Mallette, P., Norby, J., Rota, J., and Sagar, J., 2002, Geology and mineralization of the Maggie Creek District: Gold deposits of the Carlin trend: Nevada Bureau of Mines and Geology Bulletin, v. 111, p. 115-142.

Heinrich, C., Pettke, T., Halter, W., Aigner-Torres, M., Audétat, A., Günther, D., Hattendorf, B., Bleiner, D., Guillong, M., and Horn, I., 2003, Quantitative multi-element analysis of minerals, fluid and melt inclusions by laser-ablation inductively-coupled-plasma mass-spectrometry: Geochimica et Cosmochimica Acta, v. 67, no. 18, p. 3473-3497.

Hofstra, A., Snee, L., Rye, R., Folger, H., Phinisey, J., Loranger, R., Dahl, A., Naeser, C., Stein, H., and Lewchuk, M., 1999, Age constraints on Jerritt Canyon and other carlin-type gold deposits in the Western United States; relationship to mid-Tertiary extension and magmatism: Economic Geology, v. 94, no. 6, p. 769-802.

Hofstra, A. H., and Cline, J. S., 2000, Characteristics and models for Carlin-type gold deposits: Reviews in Economic Geology, v. 13, p. 163-220.

Kharaka, Y. K., and Hanor, J. S., 2014, 7.14 - Deep Fluids in Sedimentary Basins, in Turekian, H. D. H. K., ed., Treatise on Geochemistry (Second Edition): Oxford, Elsevier, p. 471-515.

Landtwing, M. R., Furrer, C., Redmond, P. B., Pettke, T., Guillong, M., and Heinrich, C. A., 2010, The Bingham Canyon porphyry $\mathrm{Cu}-\mathrm{Mo}-\mathrm{Au}$ deposit. III. Zoned copper-gold ore deposition by magmatic vapor expansion: Economic Geology, v. 105, no. 1, p. 91-118.

Longerich, H. P., Jackson, S. E., and Günther, D., 1996, Inter-laboratory note. Laser ablation inductively coupled plasma mass spectrometric transient signal data acquisition and analyte concentration calculation: Journal of Analytical Atomic Spectrometry, v. 11, no. 9, p. 899-904.

Miron, G. D., Wagner, T., Wälle, M., and Heinrich, C. A., 2013, Major and trace-element composition and pressure-temperature evolution of rock-buffered fluids in low-grade accretionary-wedge metasediments, Central Alps: Contributions to Mineralogy and Petrology, v. 165 , no. 5, p. 981-1008.

Parraga, R., Geology of the Chukar Footwall mine, Maggie Creek district, Carlin Trend, Nevada- 
A progress report, in Proceedings Symposium2005, p. 543-562.

Rhys, D., Valli, F., Burgess, R., Heitt, D., Greisel, G., and Hart, K., Controls of fault and fold geometry on the distribution of gold mineralization on the Carlin trend, in Proceedings New concepts and discoveries: Proceedings, Geological Society of Nevada Symposium 2015, Volume 1, p. 333-389.

Silberling, N. J., and Roberts, R. J., 1962, Pre-Tertiary stratigraphy and structure of northwestern Nevada: Geological Society of America Special Papers, v. 72, p. 1-56.

Simon, G., Kesler, S. E., and Chryssoulis, S., 1999, Geochemistry and textures of gold-bearing arsenian pyrite, Twin Creeks, Nevada; implications for deposition of gold in Carlin-type deposits: Economic Geology, v. 94, no. 3, p. 405-421.

Stammer, J. G., 2008, Geochemical and Mineralogical Analysis of the Chukar Footwall Gold Deposit, Northeastern Nevada [Master of Science: Colorado School of Mines, 98 p.

Stoffell, B., Appold, M., Wilkinson, J., McClean, N., and Jeffries, T., 2008, Geochemistry and evolution of Mississippi Valley-type mineralizing brines from the Tri-State and Northern Arkansas districts determined by LA-ICP-MS microanalysis of fluid inclusions: Economic Geology, v. 103, no. 7, p. 1411-1435.

Su, W., Heinrich, C. A., Pettke, T., Zhang, X., Hu, R., and Xia, B., 2009, Sediment-hosted gold deposits in Guizhou, China: products of wall-rock sulfidation by deep crustal fluids: Economic Geology, v. 104, no. 1, p. 73-93.

Theodore, T. G., Silberman, M. L., and Blake, D. W., 1973, Geochemistry and potassium-argon ages of plutonic rocks in the Battle Mountain mining district, Lander County, Nevada, US Government Printing Office.

Wilkinson, J., Everett, C., Boyce, A., Gleeson, S., and Rye, D., 2005, Intracratonic crustal seawater circulation and the genesis of subseafloor zinc-lead mineralization in the Irish orefield: Geology, v. 33, no. 10, p. 805-808.

Williams-Jones, A., Samson, I., Ault, K., Gagnon, J., and Fryer, B., 2010, The genesis of distal zinc skarns: Evidence from the Mochito Deposit, Honduras: Economic Geology, v. 105, no. 8, p. 1411-1440. 


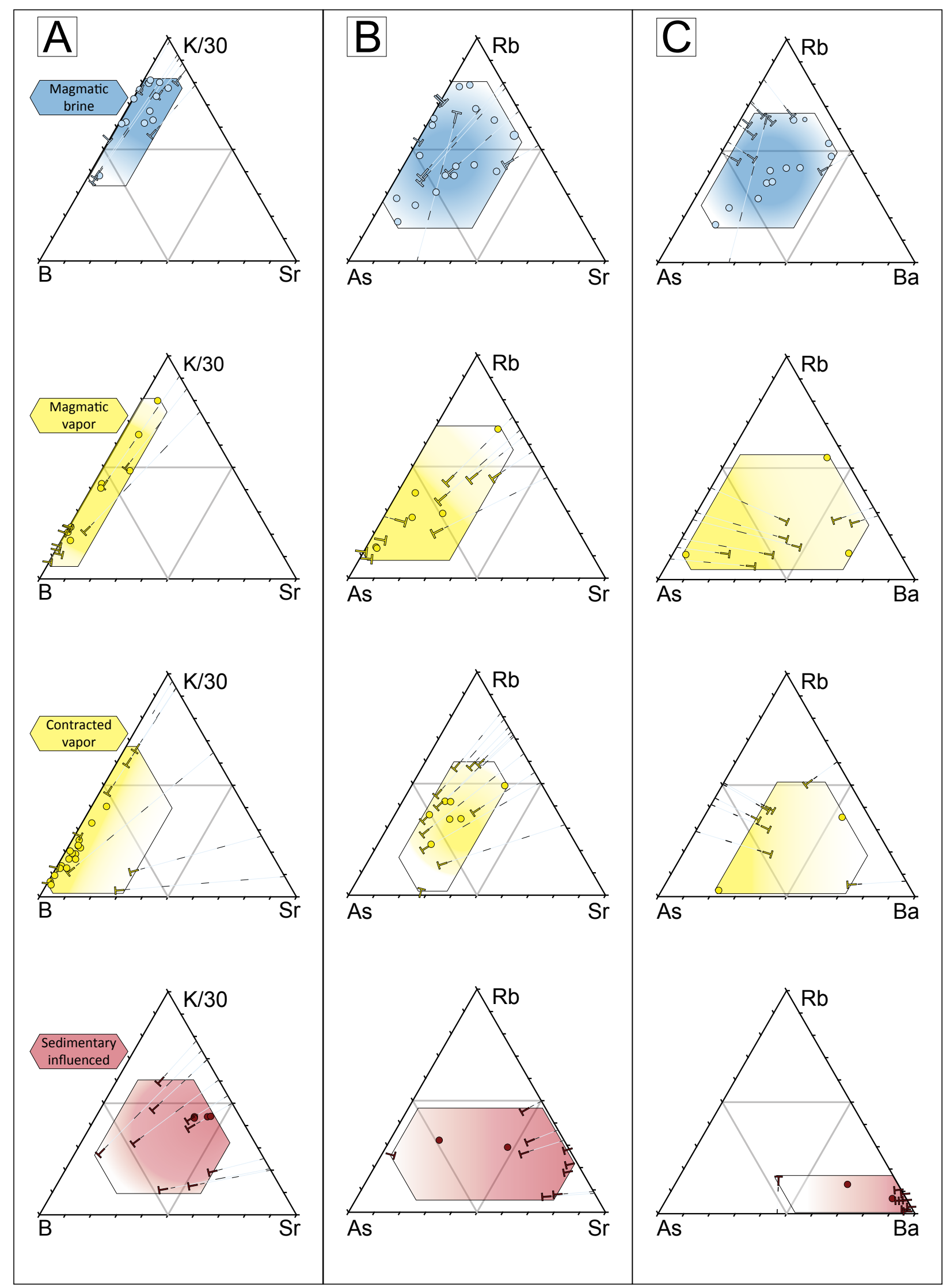

Figure DR7: Diagrams after the same systematics as Figure 2 for data obtained from Battle Mountain. The plotted data points are used to plot the hexagons used in Fig. 2B. The vapor and contracted vapour fields are merged for Fig. 2B. 
Table DR1: Fluid inclusion data table. Sample description is presented above. Rows in italic and with a grey background indicate averages and standard deviation for an assemblage. If elements were not detected ' $<$ ' indicates the limit of detection. A '-' in the Boron column indicates that B was not in the setup for those analyses. If a field is left empty data reduction by SILLS yielded a value but no meaningful peak could be observed in the LA-ICP-MS signal. An $\mathrm{x}$ in the last column indicates that this fluid inclusion analysis is displayed in at least one ternary diagram.

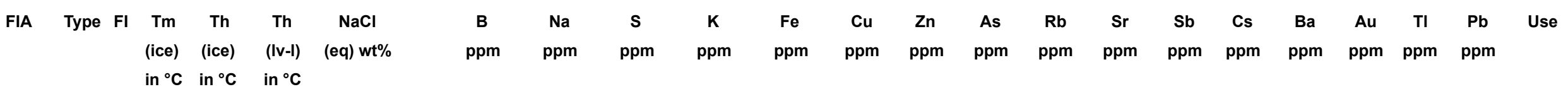

\section{Sample BMA}

\begin{tabular}{|c|c|c|c|c|c|c|c|c|c|c|c|c|c|c|c|c|c|c|c|c|c|c|c|}
\hline \multirow[t]{12}{*}{ BMA-1 } & V & 1 & -3.1 & & 365 & 5.1 & 1570 & 17500 & $<18000$ & 6900 & 6900 & $<93$ & 170 & 170 & 60 & $<22$ & 150 & 13 & $<210$ & $<7$ & $<2$ & 210 & $\mathrm{x}$ \\
\hline & V & 2 & & & 362 & & $<470$ & 16100 & $<20000$ & 10800 & 7600 & 610 & 620 & 190 & 90 & 35 & $<38$ & 18 & $<190$ & $<7$ & 4.6 & 610 & $x$ \\
\hline & V & 3 & & & 367 & & 290 & 16100 & $<8700$ & 10700 & 10400 & 220 & 520 & $<50$ & 110 & 80 & 29 & 19 & 260 & $<3$ & 3.2 & 650 & $x$ \\
\hline & V & 8 & & & 368 & & 400 & 16600 & $<16500$ & 9300 & 21300 & $<80$ & 470 & 460 & 80 & 21 & 53 & 10 & $<150$ & $<6$ & $<4$ & 740 & $\mathrm{x}$ \\
\hline & V & 9 & & & & & $<860$ & 17300 & $<32000$ & 7400 & 9700 & $<140$ & 580 & $<200$ & 70 & 84 & $<65$ & 16 & $<320$ & $<11$ & $<3$ & 840 & $x$ \\
\hline & V & 10 & & & & & $<3100$ & 17200 & $<123000$ & 7700 & $<22000$ & $<570$ & $<1263$ & $<810$ & $<190$ & $<140$ & $<260$ & $<58$ & $<1200$ & $<62$ & $<25$ & 440 & \\
\hline & V & 4 & & & & & $<320$ & 16000 & $<13000$ & 11100 & 12600 & 170 & 550 & $<78$ & 110 & 64 & 27 & 12 & 240 & $<5$ & 3.3 & 910 & $\mathrm{x}$ \\
\hline & V & 5 & & & 385 & & 140 & 11400 & $<2600$ & 23100 & 5900 & 530 & 390 & 130 & 80 & 58 & $<4$ & 7.0 & 440 & $<1$ & 1.8 & 180 & $x$ \\
\hline & V & 6 & & & 385 & & 470 & 16200 & $<12500$ & 10400 & 15500 & 860 & 760 & $<75$ & 80 & 31 & $<21$ & 19 & $<120$ & $<5$ & 5.1 & 750 & $x$ \\
\hline & V & 7 & & & & & 150 & 20000 & 1200 & 9700 & 6700 & 70 & 630 & 10 & 90 & 31 & $<1$ & 14 & 60 & $<0.3$ & 3.1 & 510 & $x$ \\
\hline & & & -3.1 & & 372 & 5.1 & 500 & 16500 & 1200 & 10700 & 10700 & 410 & 520 & 190 & 80 & 51 & 65 & 14 & 250 & & 3.5 & 590 & \\
\hline & & & & & 10.3 & & 540 & 2200 & & 4600 & 5000 & 300 & 170 & 170 & 20 & 24 & 58 & 4.0 & 160 & & 1.2 & 250 & \\
\hline \multirow[t]{6}{*}{ BMA-4 } & B & 4 & & & 250 & & $<240$ & 101000 & $<9700$ & 83100 & 141000 & 740 & 6240 & 90 & 710 & 460 & $<19$ & 88 & 530 & $<3$ & 17 & 3820 & $\mathrm{x}$ \\
\hline & B & 5 & & 231 & 265 & 33.5 & $<4500$ & 100000 & $<170000$ & 85300 & $<30000$ & $<880$ & 3670 & $<1160$ & 840 & 210 & $<340$ & 130 & $<1750$ & $<93$ & $<34$ & 2670 & $x$ \\
\hline & B & 6 & & 231 & 270 & 33.5 & $<3300$ & 111000 & $<129000$ & 55900 & 42700 & 16220 & 6610 & $<830$ & 540 & 160 & $<230$ & $<55$ & $<1270$ & $<59$ & 58 & 4230 & $\mathrm{x}$ \\
\hline & B & 7 & & & 265 & & & 103000 & $<18100$ & 75800 & 76500 & 1190 & 4690 & 120 & 630 & 250 & $<27$ & 110 & 580 & $<6$ & 21 & 3240 & $x$ \\
\hline & & & & 231 & 263 & 33.5 & & 104000 & & 75000 & 86700 & 6050 & 5310 & 100 & 680 & 270 & & 110 & 550 & & 32 & 3490 & \\
\hline & & & & 0.0 & 8.7 & 0.0 & & 5100 & & 13400 & 50000 & 8810 & 1370 & 20 & 130 & 130 & & 19 & 33 & & 22 & 680 & \\
\hline
\end{tabular}


FIA Type FI Tm Th Th $\mathrm{NaCl}$

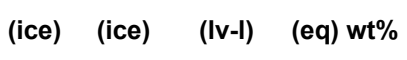
in ${ }^{\circ} \mathrm{C}$ in ${ }^{\circ} \mathrm{C}$ in ${ }^{\circ} \mathrm{C}$

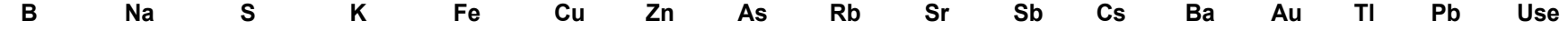

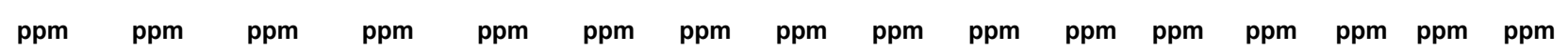

\section{Sample BMB}

\begin{tabular}{|c|c|c|c|c|c|c|c|c|c|c|c|c|c|c|c|c|c|c|c|c|c|c|}
\hline \multirow[t]{4}{*}{ BMB-1 } & V & 25 & -5.3 & 400 & 8.3 & 2200 & 29000 & $<85000$ & 8400 & 15500 & 6320 & $<960$ & $<470$ & $<150$ & $<86$ & $<125$ & $<30$ & $<760$ & $<34$ & $<9$ & 91 & $x$ \\
\hline & \multirow[t]{3}{*}{ V } & \multirow[t]{3}{*}{26} & & 400 & & 2800 & 34000 & & 18000 & $<9000$ & $<200$ & $<530$ & $<320$ & 230 & 120 & $<92$ & 43 & $<450$ & $<23$ & $<8$ & $<22$ & $x$ \\
\hline & & & -5.3 & 400 & 8.3 & 2500 & 32000 & & 13000 & 15500 & 6320 & & & 230 & 120 & & 43 & & & & 91 & \\
\hline & & & & & & 410 & 3200 & & 7100 & & & & & & & & & & & & & \\
\hline \multirow[t]{9}{*}{ BMB-2 } & V & 6 & -3.0 & 392 & 5.0 & 1520 & 18200 & 27000 & 3600 & $<2300$ & 2900 & 690 & 520 & $<18$ & $<14$ & $<16$ & 12 & $<188$ & $<6$ & 4.5 & 460 & $x$ \\
\hline & v & 7 & -3.0 & 390 & 5.0 & 1110 & 16300 & 1941 & 8500 & 2300 & 1990 & 150 & 200 & 30 & $<1$ & 6 & 12 & $<12$ & & 1.4 & 140 & $x$ \\
\hline & V & 8 & & & & 930 & 16600 & $<7100$ & 8400 & 1500 & 1170 & 250 & 160 & 30 & 8.0 & 15 & 12 & & $<2$ & $<1$ & 124 & $x$ \\
\hline & V & 9 & & & & 960 & 16600 & $<8800$ & 8300 & 4300 & 3460 & 140 & 130 & 30 & $<9$ & $<9$ & 15 & $<102$ & $<3$ & $<1$ & 139 & $x$ \\
\hline & V & 10 & & & & 1170 & 16200 & 10400 & 9300 & 3900 & 3680 & 160 & 80 & 50 & 10 & 10 & 19 & $<76$ & $<2$ & 2.3 & 159 & $x$ \\
\hline & V & 11 & & & & 1690 & 16500 & & 8700 & $<2400$ & 5290 & 310 & 370 & $<18$ & $<14$ & $<14$ & 21 & $<197$ & $<5$ & 4.0 & 290 & $x$ \\
\hline & \multirow[t]{3}{*}{ V } & \multirow[t]{3}{*}{12} & & & & 990 & 16400 & $<10100$ & 8900 & 2200 & 2670 & 140 & 200 & 20 & $<9$ & $<6$ & 11 & $<116$ & $<3$ & $<2$ & 131 & \multirow[t]{3}{*}{$x$} \\
\hline & & & -3.0 & 391 & 5.0 & 1200 & 16700 & 13000 & 8000 & 2800 & 3020 & 260 & 240 & 30 & 9.0 & 10.2 & 15.0 & & & 3.0 & 210 & \\
\hline & & & 0.0 & 1.4 & 0.0 & 300 & 700 & 12500 & 1950 & 1200 & 1320 & 200 & 150 & 10 & 1.0 & 4.4 & 4.0 & & & 1.4 & 126 & \\
\hline \multirow[t]{7}{*}{ BMB-3 } & CV & 10 & -8.5 & 352 & 12.3 & 1310 & 43000 & $<10400$ & 13900 & 1660 & $<31$ & 400 & 130 & 132 & 52 & $<14$ & 67 & $<81$ & $<3$ & 5.5 & 370 & $x$ \\
\hline & $\mathrm{CV}$ & 11 & -8.3 & 344 & 12.0 & 1570 & 42000 & $<7300$ & 14600 & $<1150$ & & 320 & 133 & 117 & 91 & 34 & 73 & & $<2$ & 2.8 & 150 & $x$ \\
\hline & $\mathrm{CV}$ & 12 & -8.2 & 352 & 11.9 & 1770 & 42000 & & 13300 & 7100 & $<37$ & 320 & 144 & 153 & 69 & 33 & 68 & $<100$ & $<2$ & 4.2 & 210 & $x$ \\
\hline & CV & 13 & -8.5 & 341 & 12.3 & 1560 & 43000 & $<20000$ & 14000 & 3500 & $<66$ & 320 & $<116$ & 128 & 105 & 41 & 73 & $<163$ & $<8$ & 5.5 & 153 & $x$ \\
\hline & \multirow[t]{3}{*}{ CV } & \multirow[t]{3}{*}{14} & & & & 1910 & 41000 & $<10500$ & 18000 & $<1610$ & $<33$ & 400 & 181 & 141 & 93 & 28 & 88 & $<90$ & $<3$ & 6.2 & 430 & \multirow[t]{3}{*}{$x$} \\
\hline & & & -8.4 & 347 & 12.1 & 1620 & 42000 & & 14800 & 4100 & & 350 & 147 & 134 & 82 & 34 & 74 & & & 4.9 & 260 & \\
\hline & & & 0.2 & 5.6 & 0.2 & 230 & 790 & & 1900 & 2800 & & 44 & 23 & 14 & 21 & 5.0 & 8.0 & & & 1.4 & 127 & \\
\hline \multirow[t]{6}{*}{ BMB-4 } & CV & 1 & -3.5 & 299 & 5.7 & $<1820$ & 17300 & $<84000$ & 6900 & $<14400$ & $<340$ & $<890$ & $<530$ & $<150$ & 131 & $<132$ & 40 & $<750$ & $<32$ & $<7$ & $<28$ & $x$ \\
\hline & $\mathrm{CV}$ & 5 & -2.8 & 295 & 4.6 & 720 & 15600 & $<19100$ & 11400 & $<3100$ & $<67$ & 370 & $<104$ & 193 & 44 & 44 & 45 & $<175$ & $<7$ & 5.8 & 123 & $x$ \\
\hline & CV & 6 & -3.0 & 289 & 5.0 & $<150$ & 16200 & $<6500$ & 9800 & 1690 & 32 & 79 & 84 & 60 & 22 & 38 & 11 & $<55$ & $<2$ & 3.9 & 130 & $x$ \\
\hline & \multirow[t]{3}{*}{$C V$} & \multirow[t]{3}{*}{7} & & & & 720 & 17900 & $<28000$ & 5400 & $<4500$ & $<107$ & $<280$ & $<149$ & $<49$ & 42 & 49 & 26 & 290 & $<10$ & $<4$ & $<10$ & $x$ \\
\hline & & & -3.1 & 294 & 5.1 & 720 & 16800 & & 8400 & 1690 & 32 & 230 & 84 & 126 & 60 & 44 & 30 & 290 & & 4.8 & 126 & \\
\hline & & & 0.4 & 5.0 & 0.5 & 0.0 & 1010 & & 2700 & & & 210 & & 94 & 49 & 5.0 & 15 & & & 1.3 & 0.0 & \\
\hline
\end{tabular}


FIA Type FI Tm Th Th $\mathrm{NaCl}$

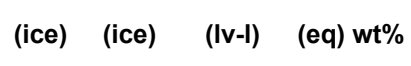
in ${ }^{\circ} \mathrm{C}$ in ${ }^{\circ} \mathrm{C}$ in ${ }^{\circ} \mathrm{C}$

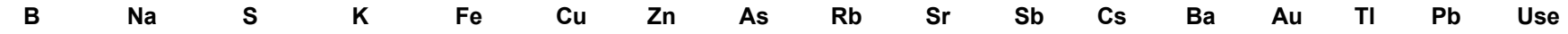

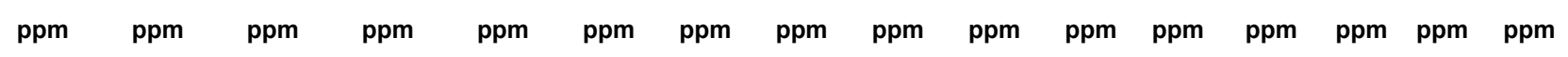

\begin{tabular}{|c|c|c|c|c|c|c|c|c|c|c|c|c|c|c|c|c|c|c|c|c|c|}
\hline \multirow[t]{11}{*}{ BMB-5 } & B & 16 & 203 & 305 & 32.0 & $<580$ & 78000 & $<21000$ & 128000 & 9300 & $<55$ & 780 & 260 & 680 & $<14$ & 67 & 171 & $<145$ & $<6$ & 20 & 240 \\
\hline & B & 17 & 203 & 305 & 32.0 & 820 & 101000 & $<5800$ & 66000 & 23000 & $<13$ & 910 & 290 & 530 & 10 & 51 & 143 & $<39$ & $<1$ & 13 & 1060 \\
\hline & B & 18 & 203 & 305 & 32.0 & 480 & 107000 & $<7400$ & 49000 & 21000 & $<19$ & 640 & 210 & 350 & 12 & 33 & 89 & $<54$ & 4.2 & 39 & 1080 \\
\hline & B & 19 & 203 & 305 & 32.0 & $<730$ & 99000 & $<26000$ & 72000 & 29000 & $<71$ & 1300 & 540 & 640 & $<18$ & 60 & 195 & $<197$ & $<8$ & 12 & 780 \\
\hline & B & 20 & 203 & 305 & 32.0 & $<790$ & 97000 & $<27000$ & 77000 & 38000 & & 1660 & 151 & 670 & 34 & $<34$ & 176 & $<196$ & $<7$ & 5.8 & 9300 \\
\hline & B & 21 & 203 & 305 & 32.0 & 1910 & 112000 & $<52000$ & 38000 & $<7300$ & $<153$ & 470 & $<300$ & 290 & 139 & $<76$ & 35 & & $<16$ & 24 & 1560 \\
\hline & B & 22 & 203 & 305 & 32.0 & 990 & 106000 & $<21000$ & 53000 & 22000 & $<60$ & 680 & 990 & 410 & 69 & $<29$ & 106 & & $<6$ & 10 & 910 \\
\hline & B & 23 & 203 & 317 & 32.0 & 1780 & 102000 & $<9300$ & 62000 & 24000 & $<20$ & 1080 & 210 & 520 & $<5$ & 83 & 131 & $<62$ & $<2$ & 2.4 & 1380 \\
\hline & B & 25 & 203 & & 32.0 & 970 & 108000 & $<9200$ & 48000 & 21000 & $<23$ & 1000 & 360 & 350 & 30 & 46 & 126 & $<67$ & $<2$ & 12 & 1300 \\
\hline & & & 203 & 307 & 32.0 & 1160 & 101000 & & 66000 & 24000 & & 950 & 380 & 490 & 49 & 57 & 130 & & 4.2 & 16 & 1960 \\
\hline & & & 0.0 & 4.2 & 0.0 & 560 & 9900 & & 26000 & 8200 & & 370 & 270 & 150 & 49 & 18 & 49 & & & 11 & 2800 \\
\hline \multirow[t]{4}{*}{ BMB-6 } & B & 26 & 285 & 320 & 37.0 & $<2100$ & 100000 & $<82000$ & 125000 & 135000 & $<260$ & 6000 & $<500$ & 1240 & 1130 & $<108$ & 600 & 1300 & $<29$ & $<10$ & 1400 \\
\hline & B & 27 & 293 & 355 & 37.6 & 770 & 124000 & $<4200$ & 60000 & 51000 & 43 & 2200 & 240 & 430 & 400 & 32 & 200 & 340 & $<1$ & 7.5 & 1350 \\
\hline & & & 289 & 338 & 37.3 & 770 & 112000 & & 92000 & 93000 & 43 & 4100 & 240 & 830 & 770 & 32 & 400 & 820 & & 7.5 & 1370 \\
\hline & & & 5.7 & 25.0 & 0.4 & & 17000 & & 45000 & 59000 & & 2700 & & 570 & 520 & & 290 & 680 & & & 32 \\
\hline \multirow[t]{10}{*}{ BMB-7 } & B & 7 & 266 & 258 & 35.7 & 350 & 105000 & & 64000 & 34000 & 23 & 1500 & 420 & 370 & 179 & 330 & 131 & 260 & $<0.4$ & 10 & 1100 \\
\hline & B & 8 & 292 & 295 & 37.6 & 360 & 89000 & $<5500$ & 75000 & 60000 & $<21$ & 2500 & 390 & 570 & 360 & & 200 & 390 & $<2$ & 10 & 1250 \\
\hline & B & 12 & 265 & 255 & 36.6 & $<1180$ & 19200 & $<55000$ & 153000 & 152000 & $<180$ & 10300 & 660 & 2800 & 620 & 940 & 1200 & 900 & $<15$ & 49 & 770 \\
\hline & B & 14 & 283 & 283 & & 780 & 93000 & $<5400$ & 67000 & 59000 & 94 & 2800 & 840 & 510 & 310 & 730 & 210 & 440 & $<1$ & 13 & 1290 \\
\hline & B & 16 & 280 & 303 & 36.7 & & 86000 & $<8200$ & 81000 & 63000 & $<31$ & 3100 & 1590 & 650 & 350 & & 240 & 410 & $<2$ & 15 & 1390 \\
\hline & B & 17 & 295 & 312 & 37.8 & & 63000 & $<15800$ & 94000 & 103000 & 240 & 5700 & 4000 & 970 & 570 & & 350 & 800 & $<4$ & 17 & 1240 \\
\hline & B & 19 & 280 & 312 & 36.7 & 570 & 95000 & $<2900$ & 73000 & 50000 & 62 & 2000 & 510 & 490 & 280 & 580 & 165 & 360 & $<0.8$ & 11 & 1110 \\
\hline & $B$ & 20 & & 295 & & 1330 & 72000 & $<12100$ & 87000 & 88000 & $<41$ & 5500 & 840 & 960 & 470 & & 410 & 540 & $<4$ & 24 & 2100 \\
\hline & & & 280 & 289 & 36.8 & 680 & 78000 & & 87000 & 76000 & 104 & 4200 & 1150 & 910 & 390 & 640 & 360 & 510 & & 19 & 1280 \\
\hline & & & 11.5 & 22.3 & 0.7 & 410 & 27000 & & 28000 & 37000 & 94 & 2900 & 1200 & 780 & 150 & 260 & 350 & 220 & & 13 & 370 \\
\hline BMB-9 & B & 1 & 118 & 317 & 28.5 & 330 & 95000 & $<5300$ & 45000 & 75000 & $<19$ & 8000 & 85 & 510 & 50 & 9.0 & 210 & 200 & $<2$ & 27 & 4700 \\
\hline
\end{tabular}


FIA Type FI Tm Th Th NaCl

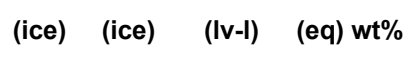
in ${ }^{\circ} \mathrm{C}$ in ${ }^{\circ} \mathrm{C} \quad$ in ${ }^{\circ} \mathrm{C}$

ppm

$\mathrm{Na} \quad \mathrm{S}$

ppm $\quad$ ppm

$\mathrm{Fe}$

$\mathrm{Cu} \quad \mathrm{Zn}$

$\begin{array}{llllll}390 & 18300<3780 & 1900<510 & <15 \quad<4\end{array}$

$\begin{array}{lllllllllllllllll}<197 & 79000 & <62000 & 145000 & 200000 & <230 & 23600 & <310 & 1380 & 1390 & 102 & 600 & 11500 & <18 & 124 & 3300 & x\end{array}$

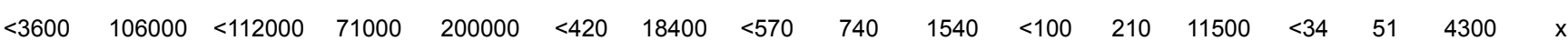

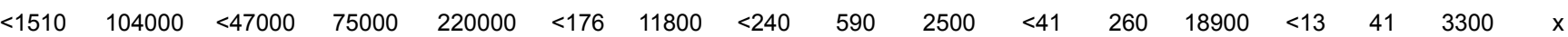

$\begin{array}{llllllllllllllll}127000 & <8200 & 18300 & 39000 & 2200 & 163 & 200 & 330 & 11 & 54 & 2600 & <2 & 10 & 1885 & x\end{array}$

$\begin{array}{lllllllllllllllll}<3600 & 132000 & <121000 & 46000 & 107000 & <420 & 2100 & 1420 & 940 & 560 & <100 & 159 & 4800 & <31 & <15 & 1381 & x\end{array}$

$\begin{array}{llllllllllllllllllll}<840 & 119000 & <28000 & 36000 & 70000 & <102 & 5700 & <150 & 310 & 530 & 24 & 159 & 4900 & <9 & 22 & 2800 & x\end{array}$

$\begin{array}{llllllllllllllllll}<4000 & 115000 & <130000 & 45000 & 42000 & <490 & 4500 & 1403 & 510 & <101 & 280 & <35 & <1210 & <44 & <20 & 2500 & x\end{array}$

$\begin{array}{ccccccccccccccc}235 & 274 & 33.8 & 112000 & 62000 & 127000 & 9800 & 1000 & 670 & 1150 & 105 & 240 & 9000 & 50 & 2800 \\ 3.4 & 1.4 & 0.2 & 17600 & 41000 & 81000 & 8500 & 720 & 400 & 840 & 125 & 191 & 6100 & 44 & 971\end{array}$

\section{Sample BMC}

\begin{tabular}{|c|c|c|c|c|c|c|c|c|c|c|c|c|c|c|c|c|c|c|c|c|c|c|}
\hline BMC-2 & $\mathrm{CV}$ & 5 & -0.9 & 303 & 1.6 & $<144$ & 6200 & $<6700$ & 780 & 1326 & 280 & 3500 & 191 & $<7$ & 74 & 14 & $<2$ & 57 & $<3$ & $<1$ & 2700 & $x$ \\
\hline \multirow[t]{5}{*}{ BMC-3 } & CV & 1 & -2.4 & 313 & 4.0 & 1640 & 14700 & $<19400$ & 3000 & $<3200$ & $<87$ & 194 & $<140$ & 30 & $<21$ & $<39$ & 33 & $<195$ & $<10$ & $<4$ & 91 & $x$ \\
\hline & $\mathrm{CV}$ & 2 & -2.5 & 303 & 4.2 & 1010 & 14000 & $<25000$ & 6600 & $<4100$ & $<93$ & $<220$ & $<150$ & 34 & 73 & 46 & $<11$ & 450 & $<11$ & $<5$ & 11 & $x$ \\
\hline & CV & 5 & & 280 & & 1490 & 14500 & $<44000$ & 7000 & $<7000$ & $<170$ & $<410$ & $<250$ & 80 & 75 & 163 & 109 & $<361$ & $<17$ & $<6$ & 157 & $x$ \\
\hline & & & -2.5 & 299 & 4.1 & 1380 & 14400 & & 5500 & & & 194 & & 48 & 74 & 105 & 71 & 450 & & & 86 & \\
\hline & & & 0.1 & 17.0 & 0.1 & 330 & 380 & & 2200 & & & & & 28 & 1.0 & 83 & 53 & & & & 73 & \\
\hline
\end{tabular}


FIA Type FI Tm Th Th $\mathrm{NaCl}$ $\begin{array}{lll}\text { (ice) } & \text { (ice) } \quad \text { (Iv-l) } & \text { (eq) } w t \%\end{array}$ B $\quad \mathrm{Na}$ $\mathrm{S}$ K in ${ }^{\circ} \mathrm{C}$ in ${ }^{\circ} \mathrm{C}$ in ${ }^{\circ} \mathrm{C}$

\begin{tabular}{|c|c|c|c|c|}
\hline BMC-4 & CV & 1 & -1.6 & \\
\hline & $\mathrm{CV}$ & 2 & -1.6 & 280 \\
\hline & CV & 3 & -1.4 & \\
\hline & $\mathrm{CV}$ & 4 & -1.5 & 286 \\
\hline & CV & 5 & -1.5 & \\
\hline & CV & 6 & -1.5 & \\
\hline & CV & 7 & -1.4 & \\
\hline & CV & 8 & -1.6 & \\
\hline & CV & 9 & -1.5 & \\
\hline & & & -1.5 & 283 \\
\hline & & & 0.1 & 4.2 \\
\hline
\end{tabular}

$\begin{array}{lllllllllllllllll}<1470 & 10500 & <57000 & <1660 & <9100 & <240 & <690 & <370 & <91 & 173 & & <22 & <520 & <27 & <9 & <22 & \\ <790 & 10500 & <30000 & <900 & <4900 & <119 & <350 & <210 & <53 & <29 & <58 & <13 & <270 & <13 & <5 & \\ <800 & 10500 & <33000 & <980 & <4900 & <116 & <350 & <181 & & 47 & & <13 & <290 & <10 & <4 & \\ <610 & 10500 & <24000 & <730 & <3800 & <98 & <320 & <171 & <53 & 95 & <44 & <10 & <220 & <11 & <4 & \\ 330 & 10500 & <9900 & <290 & <1550 & <38 & <110 & <60 & <16 & <7 & 28 & <4 & <89 & <4 & <2 & <3 \\ <510 & 10500 & <21000 & <610 & <3100 & <80 & <210 & <123 & <33 & 29 & <35 & <9 & <171 & <8 & <3 & <8 \\ <590 & 10500 & <25000 & <720 & <3800 & <91 & <260 & <148 & <41 & & <43 & <9 & & <11 & <2 & <8 \\ <1230 & 10500 & & <1400 & <7600 & <183 & <550 & <290 & <82 & 150 & <76 & <19 & <440 & <21 & <8 & <19 \\ <550 & 10500 & <22000 & 650 & <3400 & <81 & <250 & <131 & <36 & 230 & <34 & <8 & <195 & <9 & <4 & <9 & \times \\ 330 & 10500 & & 650 & & & & & & 120 & 28 & & & & & \end{array}$

\begin{tabular}{|c|c|c|c|c|c|c|c|c|c|c|c|c|c|c|c|c|c|c|c|c|c|}
\hline \multirow[t]{4}{*}{ BMC-5 } & CV & 1 & -1.3 & 275 & 2.2 & 172 & 9400 & $<3200$ & & $<480$ & $<11$ & 40 & $<15$ & 9.3 & 3.0 & $<4$ & 3.1 & $<24$ & $<1$ & $<0.3$ & 31 \\
\hline & CV & 2 & -1.4 & 277 & 2.4 & 200 & 9400 & $<1310$ & 4400 & 498 & 35 & 210 & 8.6 & 29 & 21 & 20 & 4.9 & 44 & $<0.5$ & 1.0 & 83 \\
\hline & & & -1.4 & 276 & 2.3 & 183 & 9400 & & 2400 & 498 & 35 & 123 & 8.6 & 19 & 12 & 20 & 4.0 & 44 & & 1.0 & 57 \\
\hline & & & 0.1 & 1.4 & 0.1 & 17 & & & 2900 & & & 117 & & 14 & 13 & & 1.3 & & & & 37 \\
\hline \multirow[t]{4}{*}{ BMC-6 } & $\mathrm{CV}$ & 6 & -3.4 & 306 & 5.6 & 3600 & 18900 & $<6300$ & 7900 & $<990$ & $<25$ & 320 & $<38$ & 89 & 29 & $<11$ & 118 & $<57$ & $<3$ & 4.7 & 3.0 \\
\hline & $\mathrm{CV}$ & 11 & -4.0 & 295 & 6.4 & & 22000 & $<40000$ & 8400 & $<6700$ & $<165$ & 820 & $<280$ & 101 & $<37$ & $<64$ & 60 & $<370$ & $<20$ & $<7$ & 189 \\
\hline & & & -3.7 & 300 & 6.0 & 3600 & 21000 & & 8200 & & & 570 & & 95 & 29 & & 89 & & & 4.7 & 96 \\
\hline & & & 0.4 & 7.4 & 0.6 & & 2300 & & 400 & & & 350 & & 9.0 & & & 41 & & & & 131 \\
\hline
\end{tabular}


FIA Type FI Tm Th Th NaCl

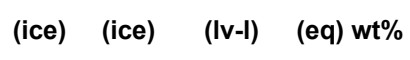
in ${ }^{\circ} \mathrm{C}$ in ${ }^{\circ} \mathrm{C} \quad$ in ${ }^{\circ} \mathrm{C}$ ppm

ppm

ppm ppm

$\mathrm{K}$
$\mathrm{ppm}$

$\mathrm{Fe} \quad \mathrm{Cu} \quad \mathrm{Zn}$

As $\quad \mathrm{Rb}$

ppm

$\begin{array}{ccccccccccccccccc}3353 & 36000 & <8700 & 15000 & 2800 & <33 & 600 & <59 & 172 & 63 & 23 & 159 & 111 & <4 & 4.9 & 270 & \mathrm{x} \\ 2600 & 28000 & <14500 & 11400 & 2400 & <56 & 740 & & 152 & <13 & <25 & 137 & <129 & <5 & 2.5 & 370 & \mathrm{x} \\ 1980 & 28000 & <18700 & 12600 & 3100 & <68 & 1970 & 210 & 83 & 76 & 214 & 112 & <151 & <7 & <3 & 980 & \mathrm{x} \\ <250 & 28000 & <9800 & 12100 & <1600 & 150 & 5000 & <64 & <15 & 29 & 443 & 4.7 & <85 & <5 & <1 & 370 & \\ 1930 & 41000 & <70000 & 22100 & <11600 & <300 & <720 & <430 & 220 & <61 & <123 & 270 & <630 & <33 & <13 & 1530 & \mathrm{x} \\ 4100 & 43000 & <31000 & 13100 & 15300 & 380 & 2500 & <194 & 91 & 51 & 152 & 181 & <280 & <17 & <6 & 10800 & \mathrm{x} \\ 2300 & 36000 & <25000 & 18000 & 7000 & <100 & 2400 & <162 & 137 & 51 & <45 & 270 & <230 & <10 & 5.2 & 1530 & \mathrm{x} \\ & 39000 & <4300 & 13700 & 2400 & <13 & 1530 & <26 & 141 & 47 & 35 & 176 & 53 & <2 & 4.5 & 1120 & \mathrm{x} \\ 2700 & 35000 & & 14800 & 5500 & 270 & 2100 & 210 & 143 & 53 & 173 & 163 & 82 & & 4.3 & 2100 & \\ 850 & 6200 & & 3600 & 5100 & 163 & 1480 & & 48 & 16 & 171 & 86 & 41 & & 1.2 & 3500 & \end{array}$

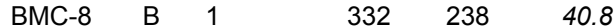

\section{Sample BMD}

\begin{tabular}{|c|c|c|c|c|c|c|c|c|c|c|c|c|c|c|c|c|c|c|c|c|c|}
\hline \multirow[t]{5}{*}{ BMD-1 } & s & 1 & -5.7 & 175 & 8.8 & $<4800$ & 35000 & $<197000$ & 32000 & $<28000$ & $<710$ & $<1773$ & $<1190$ & 390 & 4140 & $<204$ & 440 & 33000 & $<80$ & $<29$ & $<70$ \\
\hline & $S$ & 6 & -5.9 & 160 & 9.1 & $<1100$ & 36000 & $<46000$ & 25000 & $<6600$ & $<164$ & $<419$ & & 450 & 2519 & $<34$ & 240 & 12300 & $<14$ & $<6$ & $<16$ \\
\hline & $S$ & 7 & & & & $<1900$ & 35000 & $<85000$ & 20000 & & $<240$ & $<615$ & $<590$ & 290 & 2793 & $<70$ & 180 & 14200 & $<27$ & $<11$ & $<33$ \\
\hline & & & -5.8 & 167 & 8.9 & & 35000 & & 26000 & & & & & 370 & 3151 & & 290 & 19900 & & & \\
\hline & & & 0.1 & 10.4 & 0.2 & & 530 & & 6000 & & & & & 82 & 868 & & 140 & 11500 & & & \\
\hline
\end{tabular}

\section{Sample BME}

\begin{tabular}{|c|c|c|c|c|c|c|c|c|c|c|c|c|c|c|c|c|c|c|c|c|c|}
\hline \multirow[t]{7}{*}{ BME-1 } & S & 2 & -21.3 & 394 & 23.2 & 510 & 71000 & $<8700$ & 53000 & & $<27$ & 2800 & $<55$ & 690 & 1760 & $<7$ & 230 & 7100 & $<3$ & 10 & 1200 \\
\hline & S & 3 & -20.1 & 215 & 22.4 & 790 & 67000 & $<10400$ & 58000 & & $<38$ & 3500 & & 760 & 1700 & 8.7 & 270 & 7300 & $<4$ & 11 & 1030 \\
\hline & $\mathrm{s}$ & 6 & -23.6 & 195 & 24.7 & $<880$ & 78000 & $<40000$ & 51000 & $<5100$ & $<138$ & 2500 & & 610 & 1510 & $<43$ & 210 & 7200 & $<14$ & $<7$ & 1010 \\
\hline & S & 8 & -18.0 & 389 & 21.0 & 440 & 71000 & $<8600$ & 32000 & & $<26$ & 1180 & & 370 & 950 & & 97 & 5000 & $<2$ & 5.3 & 350 \\
\hline & & 9 & & & & 480 & 68000 & & 56000 & $<3100$ & $<72$ & 790 & $<116$ & 540 & 1900 & & 173 & 8300 & $<5$ & 14 & 360 \\
\hline & & & -20.8 & 298 & 22.8 & 550 & 71000 & & 50000 & & & 2100 & & 590 & 1560 & 8.7 & 196 & 7000 & & 10 & 790 \\
\hline & & & 2.3 & 108.1 & 1.6 & 157 & 4300 & & 10500 & & & 1120 & & 151 & 370 & & 65 & 1220 & & 3.4 & 400 \\
\hline
\end{tabular}


FIA Type FI Tm Th Th NaCl

$\begin{array}{lllllllllllllllll}\mathrm{B} & \mathrm{Na} & \mathrm{S} & \mathrm{K} & \mathrm{Fe} & \mathrm{Cu} & \mathrm{Zn} & \mathrm{As} & \mathrm{Rb} & \mathrm{Sr} & \mathrm{Sb} & \mathrm{Cs} & \mathrm{Ba} & \mathrm{Au} & \mathrm{TI} & \mathrm{Pb} & \mathrm{Use}\end{array}$

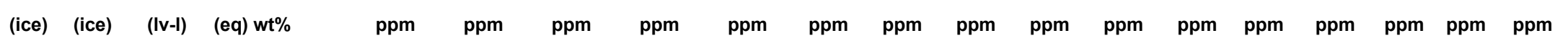
in ${ }^{\circ} \mathrm{C}$ in ${ }^{\circ} \mathrm{C}$ in ${ }^{\circ} \mathrm{C}$

\section{Sample CA}

$\begin{array}{cccccc}\text { A1-FIA5 } & \text { C } & 1 & -3.4 & >200 & 4.0 \\ \text { C } & 2 & -0.9 & >200 & 1.6 \\ \text { C } & 3 & -0.9 & >200 & 1.6 \\ \text { C } & 4 & & & \\ \text { C } & 5 & & & \\ \text { C } & 6 & & & \\ \text { C } & 7 & & & \\ \text { C } & 8 & & & \\ \text { C } & 9 & & & \\ & & -1.7 & & 2.4 \\ & & 1.4 & & 1.4\end{array}$

$\begin{array}{cccccccccccccccc}6200 & <11700 & 2300 & <12100 & <1330 & <20 & <51 & <57 & <8 & <11 & 5.3 & 250 & <3 & <1 & <3 \\ 6200 & <4300 & 2400 & <4600 & <500 & 25 & 200 & <22 & <3 & 16 & 5.0 & 28 & <1 & <0.5 & <1 \\ 6200 & <22000 & 3100 & <23000 & <2500 & <38 & <95 & <107 & <16 & 142 & <6 & <108 & <7 & <2 & <6 \\ 6200 & <8400 & 2400 & <9500 & <960 & <15 & <40 & <41 & <7 & <5 & 7.5 & 270 & <3 & <0.7 & <2 \\ 6200 & <9400 & 2000 & <10900 & <1090 & <17 & <47 & <47 & 11 & 95 & <2 & <51 & <3 & <1 & 13 \\ 6200 & <40000 & 3300 & <45000 & <4600 & <75 & <230 & <200 & <39 & <39 & <13 & <220 & <14 & <6 & <10 \\ 6200 & & 2600 & & & 25 & 200 & & 11 & 84 & 5.9 & 182 & & & 13 \\ & 490 & & & & & & & 64 & 1.4 & 134 & & & \end{array}$

$\begin{array}{llllll}\text { A1-FIA7 } & \text { C } & 1 & -3.8 & 167 & 6.2\end{array}$

$\begin{array}{lllllllllllllll}24000 & <35000 & 7100 & <53000 & <4600 & <95 & <230 & <161 & 49 & <40 & 27 & 720 & <14 & <4 & <11\end{array}$

C 2

$\begin{array}{lllll}\text { C } & 3 & -3.8 & 185 & 6.2\end{array}$

$\begin{array}{lllll}\text { C } & 4 & -3.4 & 165 & 5.6\end{array}$

$\begin{array}{ccc}-3.7 & 172.33 & 6.0 \\ 0.2 & 11.0 & 0.3\end{array}$

24000

9300

210

95

$\begin{array}{rrrr}119 & 124 & 32 & 650 \\ 100 & & 7.0 & 85\end{array}$

$\begin{array}{llllll}\text { A1-11 } & \text { C } & 1 & -3.3 & 175 & 5.4 \\ & \text { C } & 2 & -2.9 & 145 & 4.5 \\ & \text { C } & 3 & -3.5 & 145 & 5.7 \\ \text { C } & 4 & & & \\ \text { C } & 5 & & & \\ \text { C } & 6 & & & \\ & & & -3.2 & 155 & 5.2 \\ & & & 0.3 & 17.3 & 0.6\end{array}$

\begin{tabular}{|c|c|c|c|c|c|c|c|c|c|c|c|c|c|c|}
\hline 22000 & $<5000$ & 4400 & $<660$ & $<13$ & $<30$ & $<27$ & 18 & 152 & 39 & 24 & 530 & $<2$ & 0.9 & $<2$ \\
\hline 22000 & $<10600$ & 11300 & $<1400$ & 48 & $<65$ & $<59$ & 40 & 98 & $<11$ & 15 & $<65$ & $<4$ & 2.2 & $<4$ \\
\hline 22000 & $<46000$ & 5600 & $<6500$ & $<131$ & $<360$ & $<250$ & $<77$ & 230 & $<54$ & $<16$ & 1650 & $<19$ & $<5$ & $<15$ \\
\hline \multirow[t]{2}{*}{22000} & & 7100 & & 48 & & & 29 & 159 & 39 & 20 & 1090 & & 1.5 & \\
\hline & & 3700 & & & & & 16 & 65 & & 6.1 & 790 & & 0.9 & \\
\hline
\end{tabular}




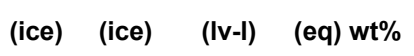

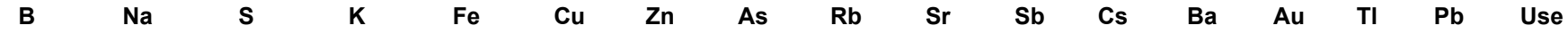

in ${ }^{\circ} \mathrm{C}$ in ${ }^{\circ} \mathrm{C}$ in ${ }^{\circ} \mathrm{C}$

A2-1

$\begin{array}{lllll}\text { C } & 1 & -3.0 & 125 & 5.0 \\ \text { C } & 2 & & 125 & \\ \text { C } & 4 & -3.6 & 143 & 5.9 \\ \text { C } & 5 & -3.0 & 134 & 5.0 \\ \text { C } & 6 & -3.0 & 149 & 5.0 \\ \text { C } & 7 & & 149 & \\ \text { C } & 8 & & 149 & \\ \text { C } & 9 & & 154 & \\ & & -3.2 & 141 & 5.2 \\ & & 0.3 & 11.5 & 0.5\end{array}$

ppm ppm ppm ppm

\begin{tabular}{|c|c|c|c|c|c|c|c|c|c|c|c|c|c|c|}
\hline 19500 & $<5500$ & 3900 & $<670$ & $<16$ & $<103$ & $<38$ & $<19$ & 112 & 60 & 22 & & $<4$ & $<1$ & $<2$ \\
\hline 19500 & $<11200$ & 2800 & $<1370$ & $<34$ & $<210$ & $<78$ & 57 & 172 & $<14$ & 27 & 650 & $<7$ & $<2$ & $<4$ \\
\hline 19500 & $<6200$ & 2400 & $<750$ & $<18$ & 560 & $<42$ & 25 & 86 & $<7$ & 15 & $<145$ & $<4$ & 1.8 & 23 \\
\hline 19500 & $<1800$ & 4900 & $<220$ & 21 & 171 & 24 & 35 & 152 & 40 & 52 & 920 & 1.3 & 1.9 & 280 \\
\hline 19500 & $<2600$ & 5300 & $<320$ & $<7$ & 680 & $<18$ & 37 & 73 & $<3$ & 16 & 123 & $<2$ & 4.5 & 81 \\
\hline 19500 & 6800 & 3000 & $<500$ & $<12$ & $<82$ & $<28$ & 31 & 167 & $<4$ & 18 & 480 & $<2$ & 1.5 & $<1$ \\
\hline \multirow[t]{2}{*}{19500} & 6800 & 3700 & & 21 & 470 & 24 & 37 & 127 & 50 & 25 & 540 & 1.3 & 2.4 & 127 \\
\hline & & 1170 & & & 270 & & 12 & 42 & 14 & 14 & 330 & & 1.4 & 133 \\
\hline
\end{tabular}

A2-3

$\begin{array}{lllll}\text { C } & 1 & -2.8 & 159 & 4.7 \\ \text { C } & 2 & -2.8 & 125 & 4.7 \\ \text { C } & 3 & -2.9 & 146 & 4.8 \\ \text { C } & 4 & -2.8 & 156 & 4.7 \\ \text { C } & 5 & -2.9 & & 4.8 \\ & & -2.8 & 147 & 4.7 \\ & & 0.1 & 15.4 & 0.1\end{array}$

\begin{tabular}{|c|c|c|c|c|c|c|c|c|c|c|c|c|c|c|}
\hline 18300 & $<3600$ & 6200 & $<410$ & $<9$ & $<62$ & $<25$ & 75 & 156 & $<4$ & 25 & 350 & $<2$ & 4.4 & 1.6 \\
\hline 18300 & $<30000$ & 2200 & $<3500$ & $<82$ & $<550$ & $<220$ & $<98$ & 210 & $<35$ & $<20$ & 760 & $<19$ & $<5$ & $<10$ \\
\hline 18300 & $<2000$ & 7700 & $<220$ & $<5$ & $<35$ & $<12$ & 100 & 69 & $<2$ & 23 & 330 & $<1$ & 3.5 & 1.5 \\
\hline \multirow[t]{2}{*}{18300} & & 5400 & & & & & 88 & 145 & & 24 & 480 & & 3.9 & 1.6 \\
\hline & & 2800 & & & & & 18 & 71 & & 1.1 & 240 & & 0.6 & 0.1 \\
\hline
\end{tabular}

A3-1

$<00 \quad<5800<2800<2400<176 \quad<980 \quad<82<25$

C 2

$\begin{array}{lll}\text { C } & 3 & -0.8\end{array}$

C $\quad 4 \quad-0.9$

C $5-0.6$

C $6-2.0$

$-1.0$

$\begin{array}{llllllllllllllll}4100 & <2500 \quad 2300 & <900 & <62 & <350 & <29 & <8 & 33 & <24 & <4 & <43 & <18 & <7 & <11 & x\end{array}$

$\begin{array}{llllll}4600 & 2300 & 7.7 & 31 & 6.6 & 34 \\ 409 & & & 8.9 & & \end{array}$


FIA Type FI Tm Th Th $\mathrm{NaCl}$

$\begin{array}{lllllllllllllllll}B & \mathrm{Na} & \mathrm{S} & \mathrm{K} & \mathrm{Fe} & \mathrm{Cu} & \mathrm{Zn} & \mathrm{As} & \mathrm{Rb} & \mathrm{Sr} & \mathrm{Sb} & \mathrm{Cs} & \mathrm{Ba} & \mathrm{Au} & \mathrm{TI} & \mathrm{Pb} & \mathrm{Use}\end{array}$

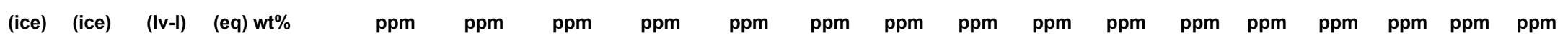
in ${ }^{\circ} \mathrm{C}$ in ${ }^{\circ} \mathrm{C}$ in ${ }^{\circ} \mathrm{C}$

\begin{tabular}{|c|c|c|c|c|c|c|c|c|c|c|c|c|c|c|c|c|c|c|c|c|c|c|}
\hline \multirow[t]{8}{*}{ A3-3 } & C & 1 & -0.9 & 190 & 1.6 & & & & & & & & & & & & & & & & & \\
\hline & C & 2 & -0.9 & 165 & 1.6 & $<390$ & 6200 & $<2500$ & 2200 & $<900$ & $<60$ & $<370$ & $<32$ & 22 & 41 & $<24$ & $<4$ & 220 & $<19$ & $<10$ & $<14$ & $x$ \\
\hline & C & 3 & -1.0 & 208 & 1.7 & $<7500$ & 6800 & $<45000$ & $<23000$ & $<18700$ & $<1340$ & $<7100$ & 1040 & $<170$ & $<148$ & $<560$ & $<126$ & $<1000$ & $<450$ & $<240$ & 860 & \\
\hline & C & 4 & -1.1 & 204 & 1.9 & $<400$ & 7500 & 3000 & 3700 & $<1000$ & $<70$ & $<380$ & $<37$ & 39 & 21 & $<24$ & 8.2 & $<62$ & $<21$ & $<10$ & $<18$ & $x$ \\
\hline & C & 5 & & & & $<240$ & 7500 & $<1550$ & 1510 & $<590$ & $<40$ & $<230$ & $<21$ & 13 & 32 & $<14$ & 8.9 & $<35$ & $<11$ & $<5$ & $<10$ & $x$ \\
\hline & C & 6 & -1.3 & 201 & 2.2 & & & & & & & & & & & & & & & & & \\
\hline & & & -1.0 & 194 & 1.8 & & 7000 & 3000 & 2500 & & & & 1040 & 24 & 31 & & 8.6 & 220 & & & 860 & \\
\hline & & & 0.2 & 17.3 & 0.3 & & 640 & & 1090 & & & & & 13 & 10 & & 0.5 & & & & & \\
\hline \multirow[t]{7}{*}{ A3-7 } & C & 1 & -2.2 & 194 & 3.7 & & & & & & & & & & & & & & & & & \\
\hline & C & 2 & -2.4 & 196 & 4.0 & 1290 & 15900 & $<7200$ & $<4800$ & $<4300$ & $<187$ & $<460$ & $<73$ & $<27$ & $<14$ & $<36$ & 35 & $<141$ & $<30$ & $<24$ & $<60$ & \\
\hline & C & 3 & -2.0 & 183 & 3.4 & 1120 & 13300 & $<19000$ & 33000 & $<11100$ & $<470$ & $<1170$ & $<196$ & $<84$ & $<43$ & 1110 & 320 & $<304$ & 141 & $<65$ & 436 & $x$ \\
\hline & C & 4 & -2.3 & 173 & 3.9 & & & & & & & & & & & & & & & & & \\
\hline & C & 5 & -2.5 & 200 & 4.2 & & & & & & & & & & & & & & & & & \\
\hline & & & -2.3 & 189 & 3.8 & 1200 & & & 33000 & & & & & & & 1110 & 179 & & 141 & & 436 & \\
\hline & & & 0.2 & 11.0 & 0.3 & 119 & 1780 & & & & & & & & & & 200 & & & & & \\
\hline \multirow[t]{9}{*}{ A3-8 } & C & 1 & -2.0 & 172 & 3.4 & 470 & 13600 & 3200 & $<1500$ & $<1300$ & $<66$ & $<152$ & 37 & $<9$ & 56 & 39 & 5.6 & $<43$ & $<8$ & $<7$ & $<24$ & $x$ \\
\hline & C & 2 & -3.2 & 159 & 5.3 & & & & & & & & & & & & & & & & & \\
\hline & C & 3 & -2.1 & 171 & 3.6 & 470 & 14000 & $<3500$ & 6400 & $<2100$ & 166 & 300 & 38 & 25 & 79 & $<17$ & $<6$ & 360 & $<13$ & $<12$ & $<30$ & $x$ \\
\hline & C & 4 & -2.1 & 178 & 3.6 & & & & & & & & & & & & & & & & & \\
\hline & C & 5 & -2.2 & 205 & 3.7 & & & & & & & & & & & & & & & & & \\
\hline & C & 6 & -1.9 & 155 & 3.2 & 470 & 12700 & $<2000$ & 1640 & $<1200$ & $<44$ & $<121$ & $<18$ & 12 & 34 & 19 & 11 & $<27$ & $<8$ & $<5$ & $<16$ & $x$ \\
\hline & C & 7 & -2.1 & 170 & 3.6 & 900 & 14000 & $<10700$ & $<7100$ & $<6500$ & $<300$ & $<680$ & 182 & $<46$ & $<22$ & $<60$ & $<27$ & $<189$ & $<52$ & $<39$ & $<82$ & \\
\hline & & & -2.2 & 173 & 3.7 & 580 & 13600 & 3200 & 4000 & & 166 & 300 & 86 & 19 & 56 & 29 & 8.1 & 360 & & & & \\
\hline & & & 0.4 & 16.2 & 0.7 & 210 & 590 & & 3400 & & & & 84 & 9.4 & 23 & 14 & 3.5 & & & & & \\
\hline
\end{tabular}


FIA Type FI $\quad \mathrm{Tm}$ Th $\quad$ Th $\quad \mathrm{NaCl}$

$\begin{array}{llllllllllllllll}B & \mathrm{Na} & \mathrm{S} & \mathrm{K} & \mathrm{Fe} & \mathrm{Cu} & \mathrm{Zn} & \mathrm{As} & \mathrm{Rb} & \mathrm{Sr} & \mathrm{Sb} & \mathrm{Cs} & \mathrm{Ba} & \mathrm{Au} & \mathrm{TI} & \mathrm{Pb}\end{array}$

Use

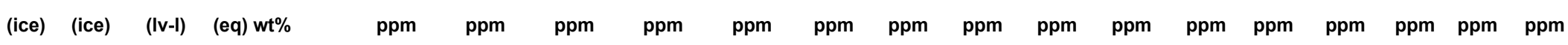
in ${ }^{\circ} \mathrm{C}$ in ${ }^{\circ} \mathrm{C}$ in ${ }^{\circ} \mathrm{C}$

\section{Sample CB}

$\begin{array}{cccccc}\text { B2-2 } & \text { C } & 1 & -1.9 & 241 & 3 . \\ & \text { C } & 2 & -2.0 & 199 & 3 . \\ & \text { C } & 3 & -1.9 & 196 & 3.2 \\ & \text { C } & 4 & -1.8 & & 3 . \\ & \text { C } & 5 & -1.7 & 203 & 2 . \\ & \text { C } & 6 & -1.7 & 195 & 2 . \\ & & & -1.8 & 207 & 3 . \\ & & & 0.1 & 19.4 & 0 .\end{array}$

$\begin{array}{llllllllllllllllll}<3800 & 11400 & <21000 & <16500 & <15800 & <540 & <1600 & 450 & <94 & <56 & 420 & <48 & <440 & <200 & <67 & <120\end{array}$

B2-3 $\quad$ C $\quad 1 \quad-3.1$

C $\quad 2 \quad-1.9$

C $\quad 3 \quad-1.7$

$\begin{array}{lll}C & 4 & -1.7\end{array}$

C 7

C $\quad 8 \quad-1.8$

C $\quad 9 \quad-1.8$

-1.8
-2
0.5

5.1

$<940 \quad 2000$

11400

450

420

$\begin{array}{llllllllllllllllll}<3800 & 11400 & <21100 & <16500 & <15800 & <540 & <1600 & 450 & <94 & <56 & 420 & <48 & <440 & <200 & <67 & <122\end{array}$

$\begin{array}{llllllllllllllllll}15500 & 11400 & <84000 & 165000 & <62000 & <2010 & <6300 & <1370 & 530 & 220 & <610 & <176 & 3800 & <770 & 240 & <449 & x\end{array}$

$\begin{array}{lllllllllllllllll}<1691 & 11400 & <9400 & 37000 & <7000 & 980 & 720 & <160 & <41 & 146 & 720 & 25 & 390 & <90 & 40 & 65 & x\end{array}$

$\begin{array}{lllllllllllllllll}<952 & 12300 & <5300 & 22000 & <3800 & 330 & 460 & <93 & <26 & 32 & <66 & <13 & <108 & <48 & <16 & <32 & x\end{array}$

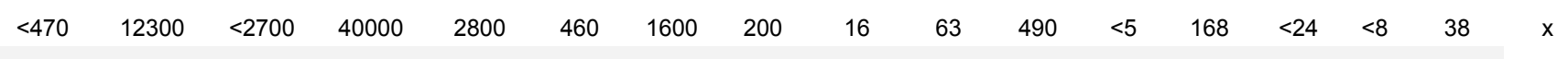

$15500 \quad 13100 \quad 8800 \quad 5700$

3100

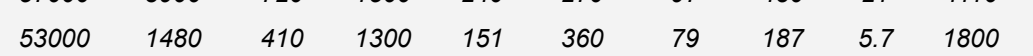

$141 \quad 18$

\section{Sample CC}

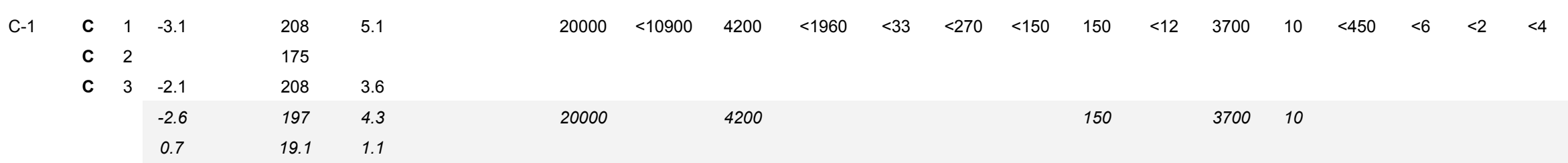




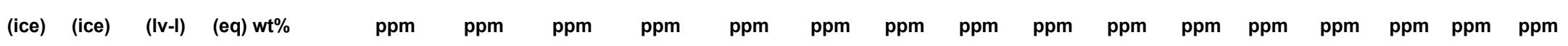
in ${ }^{\circ} \mathrm{C}$ in ${ }^{\circ} \mathrm{C}$ in ${ }^{\circ} \mathrm{C}$

\section{Sample CD}

$\begin{array}{cccccc}\text { D-1 } & \text { C } & 1 & -1.4 & 187 & 2.4 \\ & \text { C } & 2 & -1.3 & 177 & 2.2 \\ & \text { C } & 3 & -1.2 & 168 & 2.1 \\ & \text { C } & 4 & -1.0 & & 1.7 \\ \text { C } & 5 & -0.9 & & 1.6 \\ \text { C } & 6 & -1.4 & 213 & 2.4 \\ \text { C } & 7 & -1.6 & 209 & 2.7 \\ \text { C } & 8 & -1.6 & 197 & 2.7 \\ \text { C } & 9 & -1.6 & 216 & 2.7 \\ & & -1.3 & 195 & 2.3 \\ & & & 0.3 & 18.7 & 0.4\end{array}$

\begin{tabular}{|c|c|c|c|c|c|c|c|c|c|c|c|c|c|c|c|}
\hline$<270$ & 9500 & $<6500$ & 5100 & $<3800$ & 230 & $<610$ & $<66$ & $<27$ & $<12$ & $<40$ & $<13$ & $<105$ & $<29$ & $<28$ & $<140$ \\
\hline$<940$ & 8100 & $<21000$ & $<120000$ & $<11500$ & $<590$ & $<2000$ & 260 & $<90$ & $<47$ & 1440 & $<43$ & $<410$ & $<108$ & $<95$ & $<470$ \\
\hline$<860$ & 6200 & $<16100$ & $<9200$ & $<9400$ & $<580$ & $<1980$ & 810 & $<78$ & $<41$ & 670 & $<44$ & $<410$ & $<114$ & $<100$ & $<380$ \\
\hline$<360$ & 10800 & $<8100$ & $<4700$ & $<4500$ & $<260$ & $<870$ & $<87$ & $<33$ & $<18$ & 630 & $<17$ & $<141$ & $<38$ & $<34$ & $<178$ \\
\hline & 8600 & & 5100 & & 230 & & 540 & & & 910 & & & & & \\
\hline & 1970 & & & & & & 390 & & & 460 & & & & & \\
\hline
\end{tabular}

N

\section{Sample CE}

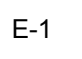

$$
\begin{array}{lll}
\text { C } & 1 & -1.0 \\
\text { C } & 2 & -1.0 \\
\text { C } & 3 & \\
\text { C } & 4 & -0.1 \\
\text { C } & 5 & -0.1
\end{array}
$$$$
\begin{array}{ccc}
-0.6 & 235 & 0.2 \\
0.5 & 0.7 \\
& 0.9
\end{array}
$$$$
\begin{array}{llllll}
\mathrm{E}-3 & \mathrm{C} & 1 & -5.7 & >260 & 8.8
\end{array}
$$$$
\text { E-4 } \quad \text { C } \quad 1 \quad-1.3 \quad 126 \quad 2.2
$$

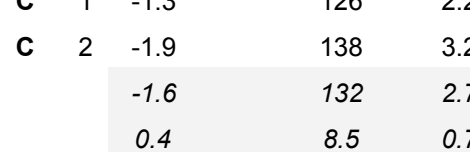

$\begin{array}{llllllllllllllll}6800 & <8900 & 9500 & <1120 & 66 & <142 & <73 & <36 & 17 & <8 & 6.7 & 480 & <3 & <1 & 11 & x \\ 6800 & <13800 & 3800 & <1750 & 137 & 270 & <119 & <51 & 14 & <13 & 6.6 & <330 & <6 & <2 & 5.2 & x \\ 6800 & <6400 & 3100 & <790 & 28 & 290 & 88 & 27 & <4 & <5 & <2 & <151 & <3 & <0.7 & 2.3 & x\end{array}$

6800

5500

$\begin{array}{ll}77 & 280 \\ 55 & 19\end{array}$

$\begin{array}{lll}88 & 27 & 16 \\ & & 2.7\end{array}$

$6.6 \quad 480$

$35000<3600 \quad 142$

$\begin{array}{lll}12700 & 660 & 3700 \\ 12700 & 660 & 3700\end{array}$

$<0.4$

$\begin{array}{lllllllll}49 & 15 & 4.2 & 10 & <3 & <0.06 & 0.2 & <0.06 & x \\ 49 & 15 & 4.2 & 10 & & & 0.2 & & \end{array}$


FIA Type FI Tm Th Th NaCl

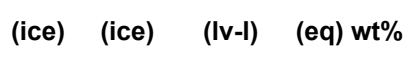
in ${ }^{\circ} \mathrm{C}$ in ${ }^{\circ} \mathrm{C}$ in ${ }^{\circ} \mathrm{C}$

E2-2

$\begin{array}{lllll}\text { C } & 1 & -1.1 & 210 & 1.9 \\ \text { C } & 2 & -1.0 & 209 & 1.7 \\ \text { C } & 3 & -0.8 & & 1.4 \\ \text { C } & 4 & & & \\ \text { C } & 5 & & 174 & \\ \text { C } & 6 & -0.9 & 182 & 1.6 \\ \text { C } & 7 & & 209 & \\ & & -1.0 & 197 & 1.7 \\ & & 0.1 & 17.4 & 0.2\end{array}$

E2-4

$\begin{array}{lllll}\text { C } & 1 & -0.9 & 208 & 1.6 \\ \text { C } & 2 & -0.9 & 195 & 1.6 \\ \text { C } & 3 & -0.8 & 150 & 1.4 \\ \text { C } & 4 & -0.3 & & 0.5 \\ & & -0.7 & 184 & 1.3 \\ & & 0.3 & 30.4 & 0.5\end{array}$

9
$\mathrm{Na}$

$\begin{array}{ccc}\mathrm{S} & \mathrm{K} \\ \mathrm{ppm} & \mathrm{ppm}\end{array}$

$\mathrm{Fe} \quad \mathrm{Cu}$

pm

u

As $\quad \mathrm{Rb} \quad \mathrm{sr}$

Sb

Cs $\quad B$

$\begin{array}{lllll}\mathrm{Au} & \mathrm{TI} & \mathrm{Pb} & \text { Use }\end{array}$

$\begin{array}{llllllllllllllllll}<2323 & 5500 & <11400 & 26000 & <6100 & <300 & <1490 & 450 & <32 & 130 & <117 & <20 & 720 & <101 & <30 & <46 & x\end{array}$

$\begin{array}{llllllllllllllllll}<1303 & 5500 & <12300 & 5400 & <3400 & <165 & <840 & <150 & <17 & <10 & 290 & <11 & <85 & <54 & <16 & <25\end{array}$

$\begin{array}{llllllllllllllllll}<2756 & 6200 & <12700 & 27000 & <6500 & <260 & <1620 & <300 & 55 & 260 & <135 & 38 & 2400 & <101 & <29 & <44 & x\end{array}$

$5700 \quad 19400$

12100

450

55

$194 \quad 290 \quad 38 \quad 1570$ 
Table DR2: Comparison of fluid inclusion types, salinities and different average element ratios from data of this study and published data from other deposits. A '-' indicates that the ratio could not be calculated or that no salinity was reported

\begin{tabular}{|c|c|c|c|c|c|c|c|c|c|c|c|c|}
\hline Study & Fluid type & $\begin{array}{l}\text { Inclusion } \\
\text { type }\end{array}$ & $\begin{array}{c}\text { Salinities } \\
\text { (wt \% } \mathrm{NaCl} \\
\text { equiv) }\end{array}$ & $\mathrm{K} / \mathrm{Na}$ & $\mathrm{Rb} / \mathrm{Na}$ & $\mathrm{Sr} / \mathrm{Na}$ & $\mathrm{Ba} / \mathrm{Na}$ & $\mathrm{As} / \mathrm{Na}$ & $\mathrm{B} / \mathrm{Na}$ & $\mathrm{Sb} / \mathrm{Na}$ & $\mathrm{As} / \mathrm{Sr}$ & $\mathrm{B} / \mathrm{Sr}$ \\
\hline \multirow[t]{6}{*}{ This study } & Magmatic fluids & & & & & & & & & & & \\
\hline & Carlin & IV & $0.2-6.5$ & 0.53 & 0.0035 & 0.0069 & 0.043 & 0.020 & 0.062 & 0.044 & 2.91 & 9.1 \\
\hline & vapor & $\mathrm{vl}$ & $5.0-12.4$ & 0.88 & 0.0042 & 0.0027 & 0.014 & 0.012 & 0.061 & 0.0023 & 4.39 & 22 \\
\hline & contracted vapor & Iv & $1.6-12.5$ & 0.45 & 0.0048 & 0.0031 & 0.0085 & 0.0060 & 0.070 & 0.0036 & 1.94 & 24 \\
\hline & brine & $\operatorname{lv}(\mathrm{h})$ & $28.5-41$ & 0.80 & 0.0072 & 0.0029 & 0.0053 & 0.0065 & 0.0079 & 0.0024 & 2.21 & 2.7 \\
\hline & sed eq & Iv & $8.8-34$ & 0.61 & 0.0070 & 0.021 & 0.128 & 0.012 & 0.0067 & 0.0012 & 0.58 & 0.32 \\
\hline \multirow{3}{*}{$\begin{array}{l}\text { Landtwing et } \\
\text { al., } 2010\end{array}$} & Magmatic fluids & & & & & & & & & & & \\
\hline & vapor & $\mathrm{vl}$ & $0.9-4$ & 0.48 & 0.0054 & 0.0036 & 0.012 & 0.012 & 0.307 & 0.0011 & 5.80 & 12 \\
\hline & brine & $\operatorname{lv}(\mathrm{h})$ & $32-57$ & 0.71 & 0.0043 & 0.0017 & 0.0021 & 0.0005 & 0.0065 & 0.00010 & 0.55 & 3.8 \\
\hline Williams-Jones & Magmatic fluids & & & & & & & & & & & \\
\hline et al., 2010 & Skarn & IV & $0.5-20.8$ & 0.24 & 0.0098 & 0.0037 & 0.0027 & 0.012 & - & - & 3.39 & - \\
\hline Kharaka and & Basin brines & & & & & & & & & & & \\
\hline Hanor, 2014 & & IV & - & 0.053 & - & 0.024 & 0.0020 & - & 0.011 & - & - & - \\
\hline Miron et al., & Metamorphic fluids & & & & & & & & & & & \\
\hline 2013 & & IV & $3.7-4$ & 0.031 & 0.00039 & 0.0020 & 0.00010 & 0.0011 & 0.042 & 0.00036 & 0.59 & 22 \\
\hline \multirow[t]{4}{*}{ Su et al., 2009} & Carlin-like ore fluids & & & & & & & & & & & \\
\hline & early & IV & $5.1-6.9$ & 0.025 & - & 0.0060 & - & 0.0054 & 0.038 & 0.00073 & 0.90 & 6.3 \\
\hline & main & Iv & $0.8-2$ & 0.062 & - & 0.0013 & - & 0.028 & 0.037 & 0.0018 & 21.43 & 29 \\
\hline & late & IV & $0.6-1.2$ & 0.033 & - & 0.0011 & - & 0.052 & 0.049 & 0.016 & 45.71 & 43 \\
\hline \multirow{4}{*}{$\begin{array}{l}\text { Stoffeli et al., } \\
2008\end{array}$} & MVT fluids & & & & & & & & & & & \\
\hline & Tri-state district & IV & $21-25$ & 0.035 & - & 0.0060 & 0.00019 & - & - & - & - & - \\
\hline & Tri-state district & IV & $21-25$ & 0.028 & - & 0.0076 & 0.00020 & - & - & - & - & - \\
\hline & Northern Arkansas & IV & $16-25$ & 0.092 & - & 0.0053 & 0.00017 & - & - & - & - & - \\
\hline Wilkinson et al., & Irish-type ore fluids & & & & & & & & & & & \\
\hline 2005 & & IV & $12-18$ & 0.037 & - & 0.021 & 0.019 & - & 0.0016 & - & - & 0.075 \\
\hline
\end{tabular}


Table DR3: Comparison of average element ratios that can be plotted in the ternary diagrams of this study. A '-' indicates that one of the elements is missing in the dataset and the ratios can therefore not be plotted in the ternary diagrams

Study

Fluid type

Magmatic fluids

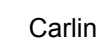

vapor

contratcted vapor

brine

sed eq

Landtwing et

al., 2010

Magmatic fluids

vapor

brine

Williams-Jones Magmatic fluids

et al., 2010

Skarn

Kharaka and

Hanor, 2014

Miron et al., Metamorphic fluids

2013

Su et al., 2009 Carlin-like ore fluids

early

main

late

Stoffeli et al., $\quad$ MVT fluids

2008

Tri-state district

Tri-state district

Northern Arkansas

Wilkinson et al., Irish-type ore fluids
$\mathrm{Rb} \quad \mathrm{B}$

$\mathrm{Sr}$

$\mathrm{K} / 30$

$\mathbf{R b}$

As

$\mathrm{Ba}$

$\mathbf{R b}$

As

0.01

0.95

0.04

0.02

0.93

0.56

0.11

0.33

0.06

0.24

0.70

$\begin{array}{lll}0.12 & 0.02 & 0.86 \\ 0.05 & 0.06 & 0.89\end{array}$

$\begin{array}{lll}0.02 & 0.02 & 0.96\end{array}$


Table DR3: Table with selected element composition of analyzed samples. Dashes indicate that no assay data was available.

\begin{tabular}{|c|c|c|c|c|c|c|c|c|c|c|c|c|}
\hline Copper Canyon & $\begin{array}{c}\mathrm{Au} \\
\mathrm{Oz} / \mathrm{t}\end{array}$ & $\begin{array}{c}\mathrm{Ag} \\
\mathrm{ppm}\end{array}$ & $\begin{array}{c}\text { As } \\
\text { ppm }\end{array}$ & $\begin{array}{c}\mathrm{Sb} \\
\mathrm{ppm}\end{array}$ & $\begin{array}{c}\mathrm{Hg} \\
\mathrm{ppm}\end{array}$ & $\begin{array}{c}\mathrm{Tl} \\
\mathrm{ppm}\end{array}$ & $\begin{array}{c}\mathrm{Cu} \\
\mathrm{ppm}\end{array}$ & $\begin{array}{c}\mathrm{Pb} \\
\mathrm{ppm}\end{array}$ & $\begin{array}{c}\mathrm{Zn} \\
\mathrm{ppm}\end{array}$ & $\begin{array}{l}\text { Mo } \\
\text { ppm }\end{array}$ & $\begin{array}{c}\mathrm{Ba} \\
\mathrm{ppm}\end{array}$ & $\begin{array}{c}\mathrm{Bi} \\
\mathrm{ppm}\end{array}$ \\
\hline BMA & - & - & - & - & - & - & - & - & - & - & - & - \\
\hline BMB & - & - & - & - & - & - & - & - & - & - & - & - \\
\hline BMC & 0.0009 & 0.47 & 2.1 & 0.37 & $<0.01$ & 1.37 & 479 & 13.1 & 21 & 1.12 & 380 & 0.57 \\
\hline BMD & - & - & - & - & - & - & - & - & - & - & - & - \\
\hline BME & - & - & - & - & - & - & - & - & - & - & - & - \\
\hline BMF & - & - & - & - & - & - & - & - & - & - & - & - \\
\hline \multicolumn{13}{|l|}{ Carlin } \\
\hline CA & 0.0133 & $>100$ & 2340 & 6770 & 43 & 20.7 & 151 & $>10000$ & 5440 & 350 & 230 & $>10000$ \\
\hline $\mathrm{CB}$ & - & - & - & - & - & - & - & - & - & - & - & - \\
\hline CC & - & - & - & - & - & - & - & - & - & - & - & - \\
\hline$C D$ & 0.319 & - & - & - & - & - & - & - & - & - & - & - \\
\hline $\mathrm{CE}$ & 0.0579 & 0.66 & 2470 & 108.5 & 9.3 & 24.4 & 42.2 & 30 & 66 & 18.9 & 70 & 1.09 \\
\hline
\end{tabular}

